\title{
Application of polychaetes in (de)coupled integrated aquaculture: production of a high-quality marine resource
}

\author{
Marit A. J. Nederlof ${ }^{1, *}$, Henrice M. Jansen ${ }^{2,3}$, Thomas G. Dahlgren ${ }^{4,5}$, Jinghui Fang ${ }^{6,7}$, \\ Sonnich Meier ${ }^{3}$, Øivind Strand ${ }^{3}$, Harald Sveier ${ }^{8}$, Marc C. J. Verdegem ${ }^{1}$, Aad C. Smaal ${ }^{1,2}$ \\ ${ }^{1}$ Department of Aquaculture \& Fisheries, Wageningen University, 6708 WD Wageningen, The Netherlands \\ ${ }^{2}$ Wageningen Marine Research, 4401 NT Yerseke, The Netherlands \\ ${ }^{3}$ Institute of Marine Research, 5005 Bergen, Norway \\ ${ }^{4}$ NORCE Norwegian Research Centre, 5006 Bergen, Norway \\ ${ }^{5}$ Gothenburg Global Biodiversity Centre, Department of Marine Sciences, University of Gothenburg, 41319 Gothenburg, Sweden \\ ${ }^{6}$ Key Laboratory for Sustainable Utilization of Marine Fisheries Resources, Ministry of Agriculture, \\ Yellow Sea Fisheries Research Institute, Qingdao 266071, PR China \\ ${ }^{7}$ Laboratory for Marine Fisheries Science and Food Production Processes, \\ Qingdao National Laboratory for Marine Science and Technology, Qingdao 266237, PR China \\ ${ }^{8}$ Lerøy Seafood Group, 5020 Bergen, Norway
}

\begin{abstract}
Capitella sp. and Ophryotrocha craigsmithi received a diet of salmon feces to evaluate their potential to convert fish waste into valuable marine products, e.g. ingredients for fish feed formulation. Production rate and body composition (focusing on fatty acid [FA] profiles) were determined for polychaetes fed fresh, acid-preserved or oven-dried salmon feces to evaluate their application in (de)coupled integrated multi-trophic aquaculture (IMTA) systems. Coupled production refers to direct integration of fish and polychaetes within the same (eco)system, while in decoupled production, units can be spatially or functionally separated. For decoupled production, preservation of fish waste is recommended. Although diets contained relatively low polyunsaturated FA (PUFA) levels (5-9\% of total FAs), both species were rich in PUFAs ( $>30 \%$ of total FAs) and contained the essential FAs for fish. Feeding Capitella sp. the acid-preserved diet enriched its FA profile. Accumulation of PUFAs, de novo synthesis and/or transfer via bacterial biomass could have played a role in the upregulation of PUFA content. Amino acid profiles indicated that these polychaetes contained the amino acids essential for fish. Highest growth for both species was observed when fed fresh feces, whereas preserved diets resulted in negative growth rates for $O$. craigsmithi, suggesting an important role of microbes in polychaete diets. Our results indicate that both species are potential valuable marine products. Given growth rates with different diets, $O$. craigsmithi seems more suitable for integration in coupled systems, while Capitella sp. is interesting for both coupled and decoupled integrated systems.
\end{abstract}

KEY WORDS: Integrated multi-trophic aquaculture - IMTA · Ophryotrocha craigsmithi · Capitella sp. · Fatty acids · Amino acids · Alternative fish feed ingredients $\cdot$ Specific growth rate

\section{INTRODUCTION}

Facing the challenge of feeding the growing world population, an important role for aquaculture is

\footnotetext{
${ }^{*}$ Corresponding author: marit.nederlof@wur.nl
}

foreseen (Duarte et al. 2009, Kobayashi et al. 2015). However, the predicted expansion of the aquaculture sector generates several environmental concerns (Ottinger et al. 2016). For example, discharges 
of metabolic wastes, uneaten feed and feces in cage aquaculture raise concerns about increasing nutrient loads to coastal ecosystems (Mente et al. 2006, Bostock et al. 2010, Holmer 2010). Expansion of the aquaculture sector also contributes to the growing need for high-quality feed (Tacon \& Metian 2015). Ingredients traditionally used in fish feed, like fish meal and oil, have become costly and limited, especially fish oil (Gatlin et al. 2007, Froehlich et al. 2018). These traditional fish feed ingredients are rich in the essential n-3 long-chain polyunsaturated fatty acids (PUFAs), which need to be provided in fish diets (Izquierdo 2005, Tocher 2015). Although terrestrialbased plant materials are often suggested as alternative feed ingredients, they lack essential n-3 PUFAs (Miller et al. 2008). Furthermore, amino acid profiles are of importance for alternative resources for fish diets; in particular, the essential amino acids should be well balanced. Terrestrial plant-based alternatives are often deficient in the essential amino acids methionine and lysine, which must be supplemented in aquatic diets (Van Der Meer \& Verdegem 1996, Gatlin et al. 2007). This highlights the need for sustainable and high-quality alternatives for fish meal and oil for aquatic diets.

Integrated multi-trophic aquaculture (IMTA) systems are a promising approach to tackle bottlenecks of high nutrient loading and the need for highquality ingredients. IMTA combines fed culture with extractive culture in such a way that waste produced by the fed culture becomes input for the extractive cultures (Troell et al. 2003, Neori et al. 2004, Chopin 2013). By smart selection of extractive species, IMTA provides opportunities to re-use nutrients in waste products and to simultaneously produce ingredients for fish feed formulation, increasing productivity of the system (Chopin 2013, Hughes \& Black 2016). It should be noted that, in Europe, the produced ingredients (i.e. extractive species) cannot be re-used in diets for the same species as the fed species in the IMTA system, due to EU regulations (European Commission 2001).

To date, most research has focused on seaweeds and bivalves as extractive species (Fang et al. 2016, Hughes \& Black 2016, Buck et al. 2018). Seaweeds extract inorganic waste nutrients, and filter feeding bivalves are able to extract fine solid waste particles from the water column (Troell et al. 2003, Handå et al. 2012, Wang et al. 2014). However, major ecological concerns are directed to the benthic ecosystem below fish farms, due to the deposition of relatively high quantities of organic waste such as feed and feces (Sarà et al. 2006, Bannister et al. 2016). Extrac- tive species that convert the solid waste fraction into valuable biomass are less studied.

Polychaetes have been suggested as extractive species in IMTA systems (Tsutsumi et al. 2005, Kinoshita et al. 2008, Brown et al. 2011, Fang et al. 2017), but their potential has not been fully explored. The high level of PUFAs measured in several polychaete species (Marsh et al. 1989, Bischoff et al. 2009, Brown et al. 2011, Salvo et al. 2015) make it interesting to explore the feasibility of using polychaetes to convert waste from fish farms into alternative resources for fish diets. Various opportunistic polychaete species are found in large densities underneath cage cultures in Norwegian fjords and coastal zones, showing their preference for organic-rich conditions (Kutti et al. 2007, Eikje 2013, Bannister et al. 2014). Capitella sp. and Ophryotrocha craigsmithi were the most abundant polychaetes found under the fish farms visited in the current study, and were therefore selected for the laboratory trials. Both species occur at high densities beneath fish farms (Kutti et al. 2007, Eikje 2013).

Species belonging to the genus Capitella are opportunistic, soft-sediment dwellers, classified as non-specialized subsurface deposit feeders, feeding on detritus and the associated microbes on this detritus (Fauchald \& Jumars 1979, Tenore 1981, Findlay \& Tenore 1982). The pioneering work of Tsutsumi et al. (2005) and Kinoshita et al. (2008) showed that cultivation of Capitella sp. underneath net pens in Kusuura Bay (Japan) resulted in rapid growth of the polychaete population and enhanced decomposition of organic matter in the enriched sediments, highlighting the potential of Capitella spp. as extractive species for IMTA systems.

Species belonging to the genus Ophryotrocha can be found in organically enriched soft sediments (Dahlgren et al. 2001), but the highest densities have been found in the deep sea on whale-falls (Dahlgren et al. 2006, Wiklund et al. 2009a,b, 2012, Salvo et al. 2014) and hard substrates underneath fish farms in Norway and Canada (Murray et al. 2012, Eikje 2013, Salvo et al. 2014). Ophryotrocha spp. are often found in communities that form a complex matrix of polychaetes, their mucus, organic waste and chemoautotrophic bacteria (Salvo et al. 2015). Fatty acid (FA) profiles revealed that both organic wastes and bacteria contributed to the diet of O. cyclops collected underneath finfish aquaculture sites in Canada (Salvo et al. 2015).

System- and site-specific characteristics determine the production success of extractive species in IMTA. In this study, polychaete species were selected with 
potential for cultivation in connection with Atlantic salmon (Salmo salar) aquaculture in Norway. Salmon aquaculture is dominated by open-water cage systems where wastes are discharged into the water column and eventually settle on the bottom (Bergheim 2012, Lekang et al. 2016, Clarke \& Bostock 2017). Recently, efforts have been made to develop (semi-)enclosed sea farm systems where waste can be collected (Lekang et al. 2016, Klebert et al. 2018). (Semi-)enclosed systems provide opportunities to develop socalled decoupled integrated systems. This term was introduced for aquaponics (Goddek et al. 2016) and refers to systems consisting of different compartments (i.e. fed species and extractive species) which are integrated as separate functional units. For these systems, spatial connection between the fish and extractive cultivation unit is not required, which provides the opportunity to collect organic wastes at the sea farm and cultivate extractive species on land or in separate sea tanks. To keep the diet for the extractive species of sufficient quality in decoupled systems, preserving the organic wastes is recommended, since fish waste degrades quickly (Beristain 2005). Drying and acidification are relatively fast and easy to apply, which is important from a commercial perspective. Both methods are known to inactivate microbial activity (Luckstadt 2008, Betoret et al. 2016) and may therefore interfere with feeding activity of the polychaetes. Acidification is also known to change the content of the diet (Hardy et al. 1984, Özyurt et al. 2016), which may affect feeding activity, but also the body content of the polychaetes. For example, FA profiles of Capitella sp. eggs differed depending on the food source of the adults (Marsh et al. 1990). During digestion, FAs are generally released from lipid molecules, but they are not always completely broken down like other nutrients (e.g. proteins). Therefore, FAs can be incorporated and stored in the body tissue in their basic form. This can subsequently result in bioaccumulation of specific FAs and can reflect an animal's diet (Iverson 2009).

Compared to FA profiles, amino acid profiles of an organism are fairly constant. Amino acids are the building blocks of proteins, and their sequence is determined in the genome. Deficiencies of essential amino acids in an animal's diet reduce the rate of protein synthesis but do not lower the level of the amino acids in proteins, resulting in amino acid profiles that are relatively constant (Mente et al. 2002, Sissener 2018). Polychaete amino acid profiles are therefore assumed to remain similar irrespective of diet, but differences between species are to be expected (Limin et al. 2006).
In the current study, we evaluated the production rate and body composition of Capitella sp. and $O$. craigsmithi fed with fresh and preserved salmon waste in order to evaluate their application in coupled and decoupled IMTA systems. Growth and survival were determined to evaluate performance. Body composition, with the focus on FA profiles, was measured to evaluate the feasibility of including polychaetes in fish feed. Amino acid profiles of the 2 polychaete species were also measured and compared. Given the impact of drying and acidification on microbial activity and diet content, we hypothesized that feeding fresh salmon waste to Capitella sp. and $O$. craigsmithi would result in higher production and higher FA content compared to feeding preserved salmon waste. Due to the lack of data on both polychaete species with respect to their diet preference, possible differences in the response of both species to the dietary treatments were also tested.

\section{MATERIALS AND METHODS}

\subsection{Study site and species}

Capitella sp. and Ophryotrocha craigsmithi were collected underneath a soft-bottom (125 m depth) and a hard-bottom (140 m depth) commercial Atlantic salmon (Salmo salar), respectively, both located in the coastal area of western Norway. Capitella sp. was collected using a van Veen grab. To collect $O$. craigsmithi, 3 iron trays $(1.2 \times 1.2 \times$ $0.1 \mathrm{~m}$ with a perforated base to allow water to pass through) covered with different plastic substrate were deployed underneath the salmon farm. Depth of tray deployment varied between 50 and $150 \mathrm{~m}$. After being submerged for $3 \mathrm{wk}$, these trays where brought to the surface and all polychaetes present in the substrates were collected. Van Veen and benthic tray samples were gently rinsed and polychaetes were collected. Immediately after collection, polychaetes were placed in an aerated tank containing water from $200 \mathrm{~m}$ depth, ensuring similar salinity and water quality parameters as their natural habitat. The polychaetes were then transported to the experimental facilities at Austevoll Research Station (Institute of Marine Research, Norway). Two different Ophryotrocha species were collected, but in this experiment only the most abundant, $O$. craigsmithi, was included (species determination was confirmed using cytochrome $c$ oxidase subunit I barcode data). The genus Capitella is represented by a 
group of morphologically similar (cryptic), but so far undescribed, species in Norwegian waters. The name 'Capitella capitata' that is often used for capitellids under fish farms around the world (e.g. Hanson \& Tenore 1981, Heip 1995) refers to a species described from Greenland (Blake 2009), and since genetic barcode data from the type locality of that species are not available, it is currently not known to what extent this species occurs in Norway. A taxonomic revision of Capitella species and other annelids in nutrient-rich habitats such as underneath fish farms, funded by the Norwegian species initiative, is ongoing (T. G. Dahlgren unpubl. data). We have therefore used the name 'Capitella sp.' for the species investigated in this study.

Polychaetes were acclimatized for $2 \mathrm{~d}$ in flowthrough, circular tanks receiving filtered $(1 \mu \mathrm{m})$ seawater $\left(34.8 \pm 0.1 \%\right.$, $\left.8.7 \pm 0.2^{\circ} \mathrm{C}\right)$ pumped from $200 \mathrm{~m}$ depth. During this acclimation period, they were fed with salmon feces which were stored in a freezer $\left(-20^{\circ} \mathrm{C}\right)$ and thawed before being fed.

At the end of the experiment, not enough polychaete material could be sampled to perform both FA and amino acid analyses. As amino acid profiles are not expected to be highly affected by the diets given, a new batch of individual $O$. craigsmithi and Capitella sp. were collected from the fish farming sites. These animals were not exposed to the experimental treatments and were solely analyzed for amino acid profiles.

\subsection{Treatments}

A $3 \times 2$ factorial design was used to evaluate the effect of diet (i.e. fresh, acid-preserved and oven-dried salmon feces) and polychaete species (i.e. Capitella sp. and O. craigsmithi) on growth, survival and final polychaete body composition ( $\mathrm{C}, \mathrm{N}$ and FAs).

For diet preparation, feces were collected twice a week from salmon (individual weight ca. 2-4 kg) kept at the sea cage facility of Austevoll Research Station. Feces were collected by stripping the fish. Using this method ensured that only feces were collected and not uneaten feed or other particulate matter. After collection, feces were directly centrifuged $(6300 \times g$ for $3 \mathrm{~min}$; Eppendorf 5810R), and liquid was carefully removed. This process was repeated twice, after which the solid fraction was homogenized and used to formulate the experimental diets.

The fresh centrifuged feces diet was directly fed to the polychaetes. The acid diet was preserved by adding formic acid $(80 \%)$ to the centrifuged feces to create a $\mathrm{pH}<4(\mathrm{pH} 3.4 \pm 0.1)$. The acidified feces were left for $24 \mathrm{~h}$ at room temperature, after which excessive liquid was carefully removed. Before feeding, the feces were washed twice with seawater to reduce acidity. Washing was done by adding seawater to the acidified feces, centrifuging for $3 \mathrm{~min}$ $(6300 \times g)$ and removing leftover liquid. The dried diet was preserved by oven-drying the centrifuged feces for $48 \mathrm{~h}$ at $100^{\circ} \mathrm{C}$. Due to the difference in time span needed for the preservation of the diets (direct use, $24 \mathrm{~h}$ and $48 \mathrm{~h}$ ), treatments started on 3 successive days, i.e. Day 1: fresh treatment, Day 2: acid treatment and Day 3: dried treatment.

\subsection{Experimental design}

At the start of the experiment, for each species, individuals of comparable lengths were selected (visually) from the acclimation tanks and divided over the experimental chambers. Simultaneously, polychaetes were collected as start sample to determine initial body weight and body composition $(\mathrm{n}=3$ $\times 30$ individuals of each species). Polychaetes collected for the start samples were then placed in a tank with clean seawater for $2 \mathrm{~d}$ in order to clear their guts. Thereafter, samples were rinsed with deionized water and stored in the freezer $\left(-20^{\circ} \mathrm{C}\right)$. Initial body composition and average individual weight were determined for the start samples and used in growth calculations (see Section 2.4).

Capitella sp. (initial weight $1.7 \pm 0.1 \mathrm{mg}$ ash-free dry weight $[\mathrm{AFDW}]$, mean $\pm \mathrm{SD}$ ) were kept in $1000 \mathrm{ml}$, cylindrical chambers $(\mathrm{n}=66$ ind. chamber $^{-1}, \mathrm{n}=4$ chambers treatment $^{-1}$ ). Inflow was at the top of the chamber, and outflow was positioned opposite to the inflow, approximately $1 \mathrm{~cm}$ above the bottom of the chamber. Glass marbles $(5 \mathrm{~mm}$, VWR) were added to each chamber (approximately $1 \mathrm{~cm}$ of the bottom was covered), to mimic natural substrates while providing the opportunity to observe the polychaetes during daily check-ups. Similar experimental chambers were used for $O$. craigsmithi (initial weight $1.9 \pm 0.1 \mathrm{mg}$ AFDW), but because of different behaviors (i.e. mucus production, community formation, active swimming in the water column) compared to Capitella sp., the design was adapted. Water inflow was positioned at the bottom of the chamber, and the outflow consisted of 2 larger openings ( $3 \mathrm{~cm}$ diameter) placed opposite each other at the top of the chamber and covered with mesh $(250 \mu \mathrm{m})$ to prevent polychaetes escaping. To mimic natural substrate conditions, a 
pre-combusted stone was added to the chamber. To standardize between species, total biomass was kept similar using 50 individuals of $O$. craigsmithi per chamber $\left(\mathrm{n}=4\right.$ chambers treatment $\left.^{-1}\right)$. Flow rate was set to $28 \pm 2 \mathrm{ml} \mathrm{min}^{-1}$, and the experimental chambers were kept in the dark during the experiment.

Polychaetes were fed 1 of the 3 experimental diets for a period of $4 \mathrm{wk}$. This time span was assumed to be long enough to distinguish potentially significant changes in FA profiles (Kirsch et al. 1998, Turner \& Rooker 2005). Treatments were randomly assigned to the chambers using the random numbers function ('RAND()') in Microsoft Excel (2016). Animals were fed twice a week. Feed was provided in excess $\left(\sim 1.5 \mathrm{~g} \mathrm{chamber}^{-1}\right.$ feeding $\left.^{-1}\right)$, for which the amount was determined based on a pilot study. During the experiment, leftover feed was always observed, confirming that feed was provided in excess. During each feeding, leftover feed was first removed and the chambers were cleaned, after which new feed was added. Flow was terminated for a minimum of $30 \mathrm{~min}$ to allow the feed to settle. During each feeding, diet samples were collected from each diet treatment (i.e. fresh, acid or dried feces) ( $\mathrm{n}=6 \mathrm{samples}^{-1 i e t^{-1}}$ feeding $\left.^{-1}\right)$ and stored in the freezer $\left(-20^{\circ} \mathrm{C}\right.$ up to $4 \mathrm{wk}$, following protocols described by Budge et al. 2006) before further analyses.

At the end of the experiment, polychaetes were counted to determine survival. Chambers were cleaned and polychaetes were left for $2 \mathrm{~d}$ in clean seawater, enabling them to empty their guts, before the final sample was collected. Sampled polychaetes were rinsed with deionized water and stored in the freezer (similar protocol as above) before further analyses.

\subsection{Analytical analyses and calculations}

Diet and polychaete samples were freeze-dried and then ground using a bullet mill. For each diet, samples collected over the time span of the experiment were pooled in such a way that each sample contained a replicate from each feeding, resulting in a total of 6 samples per diet for analyses.

\subsubsection{Subsampling}

Diets and polychaetes were analyzed for dry matter (freeze-dried), ash $\left(550^{\circ} \mathrm{C}\right.$ for $\left.6 \mathrm{~h}\right)$, gross energy (adiabatic bomb calorimetry; IKA-calorimeter C7000,
ISO 9831), $\mathrm{C}$ and $\mathrm{N}$ content and FA profiles. Gross energy was expressed in $\mathrm{kJ} \mathrm{g}^{-1}$ AFDW, and $\mathrm{C}, \mathrm{N}$ and total FAs were expressed in $\mathrm{g} \mathrm{kg}^{-1}$ AFDW.

$\mathrm{C}$ and $\mathrm{N}$ samples were combusted with an element analyzer (Flash 2000, Thermo Fisher) at $1020^{\circ} \mathrm{C}$, in the presence of oxygen, to convert $\mathrm{C}$ and $\mathrm{N}$ to $\mathrm{CO}_{2}$ and $\mathrm{NO}_{\mathrm{x}}$, respectively. Thereafter, $\mathrm{NO}_{\mathrm{x}}$ was reduced to $\mathrm{N}_{2}$ in a reduction column.

FA profiles were analyzed according to the method described by Meier et al. (2006). Samples were methylated, and the respective FA methyl esters (FAMEs) were analyzed on an HP-7890A gas chromatograph (Agilent) with a flame ionization detector (GC-FID). The FA 19:0 was added as an internal standard. Dry $\mathrm{HCl}$ in methanol $(2.5 \mathrm{M})$ was used as a methylation reagent. FAMEs were extracted using $2 \times 2 \mathrm{ml}$ of hexane. The extracted hexane was diluted or concentrated to obtain a suitable chromatographic response. One $\mu \mathrm{l}$ was injected splitless (i.e. the split was open after $2 \mathrm{~min}$ ), and the injection temperature was set to $280^{\circ} \mathrm{C}$. The column was a $25 \mathrm{~m} \times 0.25 \mathrm{~mm}$ fused silica capillary, coated with polyethylene-glycol of $0.25 \mu \mathrm{m}$ film thickness, CP-Wax $52 \mathrm{CB}$ (VarianChrompack). Helium (99.9999\%) was used as mobile phase at $1 \mathrm{ml} \mathrm{min}^{-1}$ for $45 \mathrm{~min}$ and then increased to $3 \mathrm{ml} \mathrm{min}^{-1}$ for $30 \mathrm{~min}$. The temperature of the FID was set at $300^{\circ} \mathrm{C}$. The oven temperature was programmed to hold at $90^{\circ} \mathrm{C}$ for 2 min, increase from 90 to $165^{\circ} \mathrm{C}$ at $30^{\circ} \mathrm{C} \mathrm{min}^{-1}$ and then to $240^{\circ} \mathrm{C}$ at $2.5^{\circ} \mathrm{C}$ $\mathrm{min}^{-1}$, and was then held there for $35 \mathrm{~min}$. Total analysis time was $75 \mathrm{~min}$. Fifty-eight well-defined peaks in the chromatogram were selected and identified by comparing retention times with a FAME standard (GLC-463 from Nu-Chek Prep.) and retention index maps and mass spectral libraries (GC-MS) (www.chrombox.org/index.html) performed under the same chromatographic conditions as the GC-FID (Wasta \& Mjøs 2013). Chromatographic peak areas were corrected by empirical response factors calculated from the areas of the GLC-463 mixture. The chromatograms were integrated using the EZChrom Elite software (Agilent Technologies). FAs are given as \% of total FAs. Complete FA compositions $\left(\mathrm{g} \mathrm{kg}^{-1}\right.$ AFDW) of the 2 polychaete species fed the 3 different diets are provided in Table S1 in the Supplement at www.int-res.com/articles/suppl/q011p221_supp.pdf.

Additionally collected polychaete samples (i.e. not exposed to the experimental treatments, $\mathrm{n}=4 \times 30$ individuals for Capitella sp. and $\mathrm{n}=3 \times 75$ individuals for $O$. craigsmithi) were freeze-dried, and amino acid composition was determined after hydrolysis, using an ultra-performance liquid chromatochraphy system as described by Espe et al. (2014). 


\subsubsection{Calculations}

Based on the number of individuals at the start and end of the experiment, survival (\%) per chamber was calculated. AFDW of the polychaete samples was used to calculate total biomass gain per chamber. Average individual body weight (mg AFDW) at the start and end of the experiment was determined by dividing the total AFDW of a polychaete sample (either start or end) by the number of individuals in that sample. Specific growth rate $\left(\mathrm{SGR}, \% \mathrm{~d}^{-1}\right)$ was calculated using the following formula:

$$
\mathrm{SGR}=\left\{\left[\ln \left(W_{\mathrm{f}}\right)-\ln \left(W_{\mathrm{i}}\right)\right] / T\right\} \times 100
$$

where $W_{\mathrm{f}}$ is the average individual final weight (mg AFDW), $W_{\mathrm{i}}$ is the average individual initial weight (mg AFDW), and $T$ is the number of experimental days.

\subsection{Statistical analyses}

Statistical analyses were performed in R studio 3.4.0 and PRIMER v6. Prior to statistical analysis, residuals of the data were checked for homogeneity of variance and normality using Q-Q plots and Shapiro-Wilk and Levene tests. One-way ANOVA was used to test differences in composition between diets $(C, N$, energy, total FAs and FA profiles) and to test differences in growth (biomass gain and SGR) and survival within polychaete species when fed the 3 diets. Two-way ANOVAs were used to test the effect of diet, species and their interaction on polychaete final body composition (N, C, energy, total FAs and FA profiles). Due to the low sample size $(\mathrm{n}=2), O$. craigsmithi fed the dried diet was excluded from the 2-way ANOVA. Additionally, FA classes were compared, using all data, between the 2 polychaete species using a nonparametric Mann-Whitney $U$-test.

When assumptions of homogeneity of variance and normality where violated, data were transformed. If after transformation assumptions of homogeneity of variance and normality were still violated, we used a nonparametric Kruskal-Wallis test. If only the assumption of homogeneity of variance was violated, Welch's ANOVA was used. When the ANOVA tests were significant $(p<0.05)$, treatments were compared using Tukey's HSD post hoc multiple comparison tests. When results of Welch's ANOVA were significant, treatments were compared by the Games-Howell post hoc test. Significant results found with the non-parametric test were followed by Mann-Whitney $U$-test with Bonferroni correction.

To compare FA profiles of diets and polychaetes fed with these diets, a principal component analyses (PCA) was run on all data using PRIMER v6. Data were not transformed.

\section{RESULTS}

\subsection{Diets}

Preservation affected diet composition (Table 1). Compared to the other 2 diets, preserving salmon feces by acidification resulted in a significantly lower AFDW (Mann-Whitney $U_{i} \mathrm{p}<0.01$ ), N (Tukey HSD; $p<0.001$ ) and energy (Tukey HSD; $p<0.001$ ) content, while the FA content was significantly higher (Tukey HSD; p < 0.001). Drying the salmon feces at $100^{\circ} \mathrm{C}$ resulted in a significantly higher energy content (Tukey HSD; $\mathrm{p}<0.001$ ), but a lower FA content (Tukey HSD; $\mathrm{p}<0.001$ ), compared to the fresh and acid diets. $C$ content did not differ among the 3 diets (Kruskal-Wallis; $\mathrm{p}=0.097$ ).

\subsection{Growth and survival}

The number of individuals in all experimental chambers with Ophryotrocha craigsmithi reduced over the experimental period. This was partly the result of mortality, but we cannot rule out that some animals might have escaped. Survival of $O$. craigsmithi was (mean $\pm \mathrm{SD}$ ) $80 \pm 6,75 \pm 13$ and $48 \pm 39 \%$ for the fresh, acid-preserved and oven-dried diet, respectively, with no statistical differences between the dietary treatments (Welch's ANOVA; $\mathrm{p}=0.36$ ). Despite the reduced number of individuals at the end

Table 1. Composition of the experimental diets, i.e. fresh salmon feces and salmon feces preserved by acidification (formic acid, $\mathrm{pH}<4$ ) or by oven-drying at $100^{\circ} \mathrm{C}$. Values are mean $\pm \mathrm{SD}(\mathrm{n}=6$ samples treatment $\left.{ }^{-1}\right)$. AFDW: ash-free dry weight ( $\mathrm{g} \mathrm{kg}^{-1}$ dry matter); FA: fatty acid. $\mathrm{C}, \mathrm{N}$ and total FAs are given in $\mathrm{g} \mathrm{kg}^{-1} \mathrm{AFDW}$, energy is given in $\mathrm{kJ} \mathrm{g}^{-1}$ AFDW. ${ }^{* * *} \mathrm{p}<0.001,{ }^{* *} \mathrm{p}<0.01,{ }^{*} \mathrm{p}<0.05$, ns: not significant. Means within a row lacking a common subscript differ significantly $(p<0.05)$

\begin{tabular}{|lrrrc|}
\hline & Fresh & Acid & Dried & Significance \\
\hline AFDW & $777 \pm 5^{\mathrm{a}}$ & $675 \pm 47^{\mathrm{b}}$ & $774 \pm 4^{\mathrm{a}}$ & $* *$ \\
$\mathrm{C}$ & $425 \pm 12$ & $424 \pm 15$ & $441 \pm 15$ & $\mathrm{~ns}$ \\
$\mathrm{~N}$ & $24 \pm 1^{\mathrm{a}}$ & $15 \pm 2^{\mathrm{b}}$ & $24 \pm 1^{\mathrm{a}}$ & ${ }^{* * *}$ \\
Energy & $18.0 \pm 0.3^{\mathrm{b}}$ & $16.9 \pm 0.4^{\mathrm{c}}$ & $18.5 \pm 0.2^{\mathrm{a}}$ & ${ }^{* * *}$ \\
Total FAs & $62 \pm 0.4^{\mathrm{b}}$ & $72 \pm 0.6^{\mathrm{a}}$ & $59 \pm 0.5^{\mathrm{c}}$ & ${ }^{* * *}$ \\
\hline
\end{tabular}


Fig. 1. Biomass gain of (A) Capitella sp. and (B) Ophryotrocha craigsmithi fed 3 different diets (fresh, acid-preserved and oven-dried). Biomass gain was calculated based on total biomass at the start and end in each experimental chamber. Boxes represent the interval between the lower and the upper quartiles of the distributions. Crosses are the mean values $(n=4$ tanks treatment $\left.{ }^{-1}\right)$. Vertical bars show minimal and maximal values. Boxes lacking a common subscript letter differ significantly $(\mathrm{p}<0.05)$
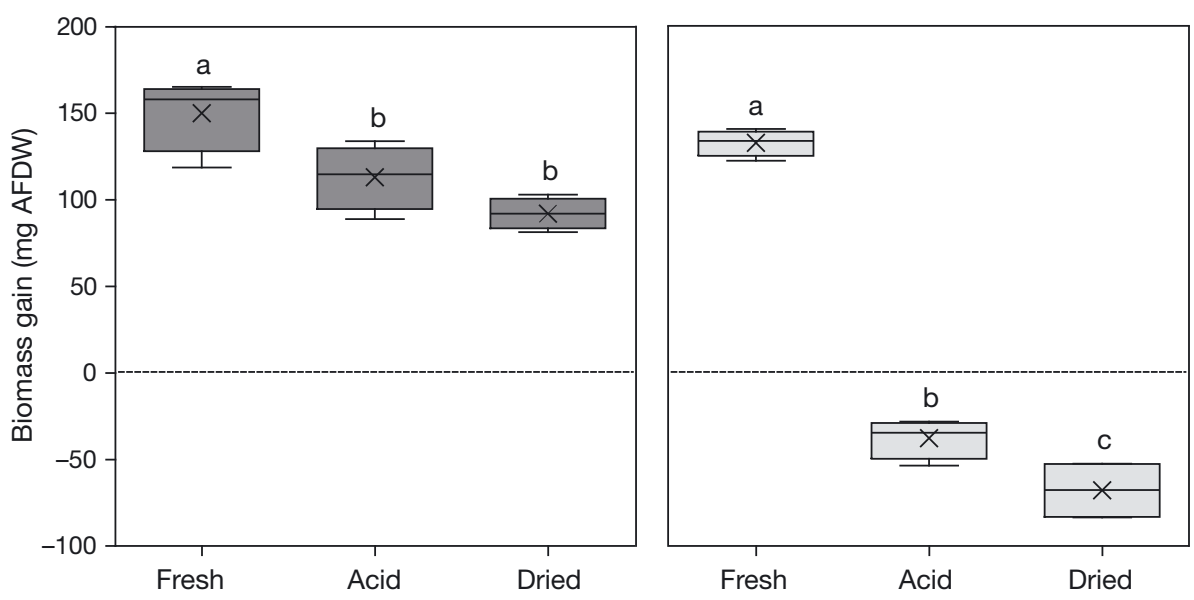

of the experimental period, total biomass of O. craigsmithi fed the fresh diet increased during the experimental period, resulting in a biomass gain of $133 \pm$ $8 \mathrm{mg}$ AFDW (Fig. 1). Feeding O. craigsmithi the preserved diets resulted in a negative biomass gain (mg AFDW), which were both significantly lower compared to O. craigsmithi fed the fresh diet (Fig. 1; Tukey HSD; $\mathrm{p}<0.001)$. The same pattern was observed for the $\mathrm{SGR}_{;} O$. craigsmithi fed the fresh salmon feces had a significantly (Games-Howell; $\mathrm{p}<$ $0.001)$ higher SGR (mean $\pm \mathrm{SD}_{3} 3.56 \pm 0.30 \% \mathrm{~d}^{-1}$ ) than $O$. craigsmithi fed the preserved diets (mean \pm $\mathrm{SD}_{i}-0.70 \pm 0.32$ and $-1.02 \pm 1.06 \% \mathrm{~d}^{-1}$ for the acid and dried treatments, respectively). The greatest reduction in biomass was observed for $O$. craigsmithi fed the dried diet, which had a significantly lower biomass gain than both other diets (Fig. 1; Tukey HSD; $\mathrm{p}=0.001$ ).

In most experimental chambers with Capitella sp. (except for 2 chambers), the number of individuals increased, probably due to reproduction, resulting in $>100 \%$ of individuals present at the end of the experiment compared to the start (respectively $104 \pm 6 \%$,
$121 \pm 8 \%$ and $111 \pm 9 \%$ for the fresh, acid and dried diets). At the end of the experiment, significantly more individuals were present in the chambers fed the acid diet compared to chambers assigned to the fresh treatment (Tukey HSD; $\mathrm{p}<0.05$ ). In all Capitella sp. treatments, biomass (mg AFDW) increased during the experimental period (Fig. 1). Total biomass gain (mg AFDW) was significantly higher in the fresh treatment compared to both other treatments (Fig. 1; Tukey HSD; p < 0.001). This was also reflected in the significantly higher SGR (Tukey HSD; $\mathrm{p}<0.01)$ for Capitella sp. fed the fresh diet $(2.56 \pm$ $\left.0.34 \% \mathrm{~d}^{-1}\right)$, compared to Capitella sp. fed the preserved diets $\left(1.59 \pm 0.36\right.$ and $1.58 \pm 0.38 \% \mathrm{~d}^{-1}$ for the acid and dried treatments, respectively). Yet, in contrast to $O$. craigsmithi, there was a net gain of Capitella sp. biomass with all diets tested.

\subsection{Body composition}

The initial and final body composition of $O$. craigsmithi and Capitella sp. are shown in Table 2. Except

Table 2. Body composition of the 2 polychaete species (Ophryotrocha craigsmithi and Capitella sp.) fed 3 different diets (defined in Table 1). Values are mean $\pm \mathrm{SD}$. For initial and final body composition, $\mathrm{n}=3$ and 4 tanks treatment ${ }^{-1}$, respectively, except for $C$ and $\mathrm{N}$ content of $O$. craigsmithi (acid), where $\mathrm{n}=3$ tanks, and total FAs of $O$. craigsmithi (dried), where $\mathrm{n}=2$. For some samples, not enough material was available to analyze all body composition parameters. This is indicated by ND (not determined). D: diet; S: species; other abbreviations, units and significance as in Table 1

\begin{tabular}{|c|c|c|c|c|c|c|c|c|c|c|c|}
\hline & \multirow{3}{*}{ Initial } & \multicolumn{3}{|c|}{ O. craigsmithi- } & \multirow{3}{*}{ Initial } & \multicolumn{3}{|c|}{ - Capitella sp.- } & \multicolumn{3}{|c|}{ Significance } \\
\hline & & & — Final & & & & — Final & & $\mathrm{D}$ & $\mathrm{S}$ & $\mathrm{D}^{*} \mathrm{~S}$ \\
\hline & & Fresh & Acid & Dried & & Fresh & Acid & Dried & & & \\
\hline AFDW & $508 \pm 84$ & $730 \pm 41$ & $705 \pm 49$ & $794 \pm 69$ & $922 \pm 19$ & $902 \pm 17$ & $841 \pm 26$ & $860 \pm 24$ & * & $* * *$ & ns \\
\hline $\mathrm{C}$ & $396 \pm 18$ & $441 \pm 14$ & $428 \pm 8$ & ND & $469 \pm 18$ & $485 \pm 9$ & $488 \pm 4$ & $484 \pm 4$ & ns & $* * *$ & ns \\
\hline $\mathrm{N}$ & $95 \pm 5$ & $112 \pm 1^{\mathrm{a}}$ & $109 \pm 3^{a}$ & ND & $96 \pm 3$ & $99 \pm 1^{b}$ & $101 \pm 3^{b}$ & $99 \pm 0.3^{b}$ & ns & $* * *$ & $*$ \\
\hline $\mathrm{C}: \mathrm{N}$ ratio & $4.2 \pm 0.1$ & $3.9 \pm 0.1$ & $3.9 \pm 0.1$ & ND & $4.9 \pm 0.1$ & $4.9 \pm 0.1$ & $4.8 \pm 0.1$ & $4.9 \pm 0.0$ & ns & $* * *$ & ns \\
\hline Energy & ND & $23 \pm 2$ & $21 \pm 2$ & ND & $15 \pm 5$ & $22 \pm 1$ & $22 \pm 0.5$ & $22 \pm 0.2$ & $\mathrm{~ns}$ & $\mathrm{~ns}$ & ns \\
\hline Total FAs & ND & $104 \pm 11^{b}$ & $86 \pm 8^{\mathrm{b}, \mathrm{c}}$ & 73 & ND & $97 \pm 11^{\mathrm{b}, \mathrm{c}}$ & $125 \pm 4^{\mathrm{a}}$ & $80 \pm 4^{\mathrm{C}}$ & $* * *$ & $\mathrm{~ns}$ & $* * *$ \\
\hline
\end{tabular}


for the energy and total FA content, a species effect was observed for all other parameters (2-way ANOVA; $\mathrm{p}<0.001)$. At the end of the experiment, Capitella sp. had a significantly higher AFDW, C and $\mathrm{C}: \mathrm{N}$ ratio compared to $O$. craigsmithi, while the latter had a significantly higher $\mathrm{N}$ content (2-way ANOVA; $\mathrm{p}<0.001)$.

Diets affected AFDW and FA content of the polychaetes (2-way ANOVA; $p<0.05)$. A significantly lower AFDW content was found when polychaetes were fed the acid diet, compared to polychaetes fed the dried diet (Tukey HSD; $\mathrm{p}<0.05$ ). Total FA content of polychaetes fed the dried diet $\left(80 \mathrm{~g} \mathrm{~kg}^{-1}\right.$ AFDW) was significantly lower compared to polychaetes fed the other 2 diets (Tukey HSD; $\mathrm{p}<0.05$ ).

An interaction effect between diet and species was found for $\mathrm{N}$ and total FA body content (2-way ANOVA $; \mathrm{p}<0.05)$. At the end of the experiment, $O$. craigsmithi fed the fresh or acid diet had a significantly higher $\mathrm{N}$ content compared to Capitella sp. fed the fresh, acid or dried diet (Tukey HSD; p < 0.05). Total FA content was highest in Capitella sp. fed the acid diet (125 $\mathrm{g} \mathrm{kg}^{-1}$ AFDW), which was significantly higher compared to the other treatments (Tukey HSD; p < 0.05). Interestingly, O. craigsmithi fed the acid diet had one of the lowest FA contents (86 $\mathrm{g} \mathrm{kg}^{-1}$ AFDW), which was significantly lower than the FA content of Capitella sp. fed the acid diet (Tukey HSD; p < 0.001). The lowest FA content was observed for $O$. craigsmithi fed the dried diet (73 $\mathrm{g}$ $\mathrm{kg}^{-1}$ AFDW).

Amino acid analyses showed that both species contained all essential amino acids (Fig. 2). Higher levels of each essential amino acid were observed for $O$. craigsmithi compared to Capitella sp. In particular, lysine and isoleucine were high in $O$. craigsmithi (respectively $32.7 \pm 0.6$ and $23.6 \pm 1.2 \mathrm{mg} \mathrm{g}^{-1}$ dry matter) (Fig. 2).

\subsection{FAs}

FA composition of the diets was dominated by saturated FAs (SFAs, $>65 \%$ ), followed by monounsaturated FAs (MUFAs, > 25\%) (Table 3). PUFAs only had a minor contribution to the total FA composition of the diets $(<10 \%)$, resulting in a low $(<0.15)$ PUFA: SFA ratio for the diets (Table 3 ). The main SFAs in the diets were 18:0, 16:0 and 22:0, while MUFAs were dominated by 18:1 (n-9) (Table 3). Preservation of the salmon feces affected the FA profile (Table 3). Fresh salmon feces had a significantly lower SFA content compared to the preserved salmon feces (Table 3; Mann-Whitney $U_{i} \mathrm{p}<0.01$ ). MUFA and PUFA content, on the other hand, were significantly higher in the fresh feces compared to the preserved feces (Table 3 ; respectively Mann-Whitney $U$ and Games-Howell; $\mathrm{p}<0.01$ ). The lowest PUFA content was measured in the feces preserved by acidification, of which both total PUFAs and the n-6 PUFAs were significantly lower than in the fresh and dried feces (Table 3; Games-Howell; p < 0.001).

All FA classes except MUFAs were significantly different between the 2 polychaete species (Fig. 3; Mann-Whitney $\left.U_{i} \mathrm{p}<0.05\right)$. FA composition of Capitella sp. was dominated by MUFAs (40 $\pm 5 \%$ of total FAs), followed by PUFAs (30 $\pm 10 \%$ of total FAs) and SFAs ( $29 \pm 5 \%$ of total FAs; Fig. 3). O. craigsmithi was rich in PUFAs ( $44 \pm 1 \%$ of total FAs) and MUFAs $(36 \pm 2 \%$ of total FAs; Fig. 3$)$. Both $n-3$ and n-6 PUFAs

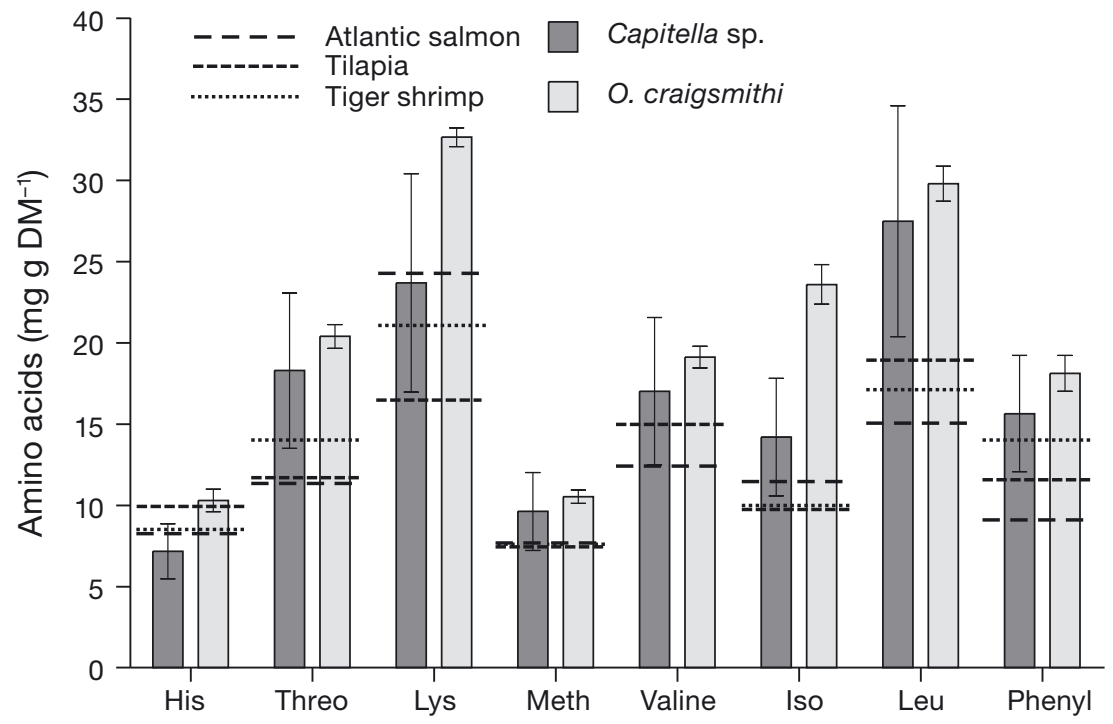

Fig. 2. Essential amino acid body composition of Capitella sp. and Ophryotrocha craigsmithi measured in this study and essential amino acid requirements for Atlantic salmon, tilapia and tiger shrimp as reported in NRC (2013). Bars are mean values $(\mathrm{n}=4$ samples for Capitella sp. and 3 samples for $O$. craigsmithi); error bars are SD. His: histidine; Threo: threonine; Lys: lysine; Meth: methionine; Iso: isoleucine; Leu: leucine; Phenyl: phenylalanine 
Table 3. FA composition (\% of total FAs) of the diets (defined in Table 1). Only FAs contributing $>1 \%$ of the total FAs are considered here, as well as ${ }^{1}$ linoleic acid, ${ }^{2}$ arachidonic acid, ${ }^{3} \alpha$-linolenic acid, ${ }^{4}$ eicosapentaenoic acid and ${ }^{5}$ docosahexaenoic acid. All FAs ( $>0.1 \%$ of total FAs) were used to calculate the sum of saturated, monounsaturated and polyunsaturated FAs (SFAs, MUFAs and PUFAs), n-6 and n-3 PUFAs or non-methylene interrupted (NMI) FAs. Values are given as mean $\pm \mathrm{SD}\left(\mathrm{n}=6 \mathrm{samples}^{\mathrm{diet}}{ }^{-1}\right.$, except for the acid diet where $n=4)$. Significance as in Table 1

\begin{tabular}{|c|c|c|c|c|}
\hline & Fresh & Acid & Dried & Significance \\
\hline SFAs & $67 \pm 2^{\mathrm{a}}$ & $71 \pm 1^{b}$ & $71 \pm 1^{b}$ & $* *$ \\
\hline $14: 0$ & $2.4 \pm 0.2$ & $2.6 \pm 0.0$ & $2.5 \pm 0.2$ & ns \\
\hline $16: 0$ & $18.6 \pm 0.6^{b}$ & $20.8 \pm 0.2^{\mathrm{a}}$ & $19.2 \pm 0.9^{b}$ & $* * *$ \\
\hline $18: 0$ & $20.9 \pm 0.9$ & $21.8 \pm 0.3$ & $22.5 \pm 0.9$ & ns \\
\hline $20: 0$ & $4.9 \pm 0.2$ & $5.2 \pm 0.1$ & $5.3 \pm 0.2$ & $\mathrm{~ns}$ \\
\hline $22: 0$ & $18 \pm 1$ & $18.4 \pm 0.3$ & $20 \pm 1$ & ns \\
\hline $24: 0$ & $0.95 \pm 0.03^{b}$ & $1.04 \pm 0.01^{\mathrm{a}}$ & $1.04 \pm 0.02^{\mathrm{a}}$ & $* *$ \\
\hline MUFAs & $33 \pm 2^{\mathrm{a}}$ & $29 \pm 1^{b}$ & $29 \pm 1^{b}$ & $* *$ \\
\hline $18: 1(n-7)$ & $1.33 \pm 0.07$ & $1.28 \pm 0.03$ & $1.20 \pm 0.07$ & $\mathrm{~ns}$ \\
\hline $18: 1(n-9)$ & $14 \pm 1$ & $13 \pm 1$ & $12 \pm 0.4$ & ns \\
\hline 20:1 (n-9) & $2.1 \pm 0.09^{\mathrm{a}, \mathrm{b}}$ & $2.2 \pm 0.04^{\mathrm{a}}$ & $1.97 \pm 0.06^{b}$ & $* *$ \\
\hline $22: 1(n-11)$ & $2.89 \pm 0.06^{\mathrm{a}}$ & $2.91 \pm 0.05^{\mathrm{a}}$ & $2.73 \pm 0.03^{b}$ & $* * *$ \\
\hline $24: 1(\mathrm{n}-9)$ & $1.17 \pm 0.01^{\mathrm{c}}$ & $1.29 \pm 0.02^{\mathrm{a}}$ & $1.20 \pm 0.02^{b}$ & $* * *$ \\
\hline PUFAs & $9 \pm 0.4^{\mathrm{a}}$ & $5 \pm 0.2^{\mathrm{c}}$ & $6 \pm 0.2^{\mathrm{b}}$ & $* * *$ \\
\hline PUFAs (n-6) & $4.7 \pm 0.3^{\mathrm{a}}$ & $2.3 \pm 0.1^{\mathrm{c}}$ & $3.6 \pm 0.1^{b}$ & $* * *$ \\
\hline $18: 2(n-6)^{1}$ & $4.3 \pm 0.2^{\mathrm{a}}$ & $2.0 \pm 0.2^{\mathrm{c}}$ & $3.3 \pm 0.1^{b}$ & $* * *$ \\
\hline $20: 4(\mathrm{n}-6)^{2}$ & $0.07 \pm 0.004^{\mathrm{a}}$ & $0.03 \pm 0.005^{c}$ & $0.04 \pm 0.003^{b}$ & $* * *$ \\
\hline PUFAs (n-3) & $3.6 \pm 0.1^{\mathrm{a}}$ & $2.3 \pm 0.1^{\mathrm{b}}$ & $2.4 \pm 0.1^{\mathrm{b}}$ & $* * *$ \\
\hline $18: 3(n-3)^{3}$ & $0.8 \pm 0.08^{\mathrm{a}}$ & $0.3 \pm 0.02^{\mathrm{c}}$ & $0.4 \pm 0.02^{\mathrm{b}}$ & $* * *$ \\
\hline $20: 5(n-3)^{4}$ & $0.6 \pm 0.03^{\mathrm{a}}$ & $0.4 \pm 0.01^{\mathrm{b}}$ & $0.4 \pm 0.02^{\mathrm{b}}$ & $* * *$ \\
\hline $22: 6(n-3)^{5}$ & $0.8 \pm 0.01^{\mathrm{a}}$ & $0.4 \pm 0.02^{\mathrm{b}}$ & $0.4 \pm 0.02^{\mathrm{b}}$ & $* * *$ \\
\hline NMI FAs & $0.4 \pm 0.02^{\mathrm{a}}$ & $0.4 \pm 0.01^{\mathrm{a}}$ & $0.4 \pm 0.03^{b}$ & $* *$ \\
\hline PUFA:SFA & $0.13 \pm 0.009^{a}$ & $0.07 \pm 0.004^{\mathrm{c}}$ & $0.09 \pm 0.004^{b}$ & $* * *$ \\
\hline DHA:EPA & $1.32 \pm 0.09^{\mathrm{a}}$ & $1.19 \pm 0.02^{\mathrm{b}}$ & $1.18 \pm 0.04^{\mathrm{b}}$ & ${ }^{*}$ \\
\hline
\end{tabular}

were significantly higher in O. craigsmithi than in Capitella sp. (MannWhitney $U_{i} \mathrm{p}<0.01$ ). The difference in FA classes between the polychaete species is also reflected in their PUFA: SFA ratio, which was significantly higher for $O$. craigsmithi (Mann-Whitney $U_{i} \mathrm{p}<0.001$ ).

An interaction effect between species and diet was found for all FA classes (Table 4 ; 2-way ANOVA; $\mathrm{p}<0.05$ ). This interaction effect revealed that except for non-methylene interrupted (NMI) FAs, Capitella sp. fed the fresh or dried diet significantly differed in FA classes from the other treatments (Table 4; Tukey HSD; p < 0.05); MUFA content was significantly higher (Tukey HSD; $\mathrm{p}$ $<0.001$ ), while PUFA content was significantly lower (Tukey HSD; p < $0.001)$. This was also reflected in the $n-$ 3 and n-6 PUFAs, which were both lowest for Capitella sp. fed the fresh and dried diets (Tukey HSD; $\mathrm{p}<0.001$ ). An interaction effect between diet and species was also observed for the PUFA:SFA ratio (2-way ANOVA; $\mathrm{p}<$ 0.05). Feeding Capitella sp. with the acid diet significantly increased their

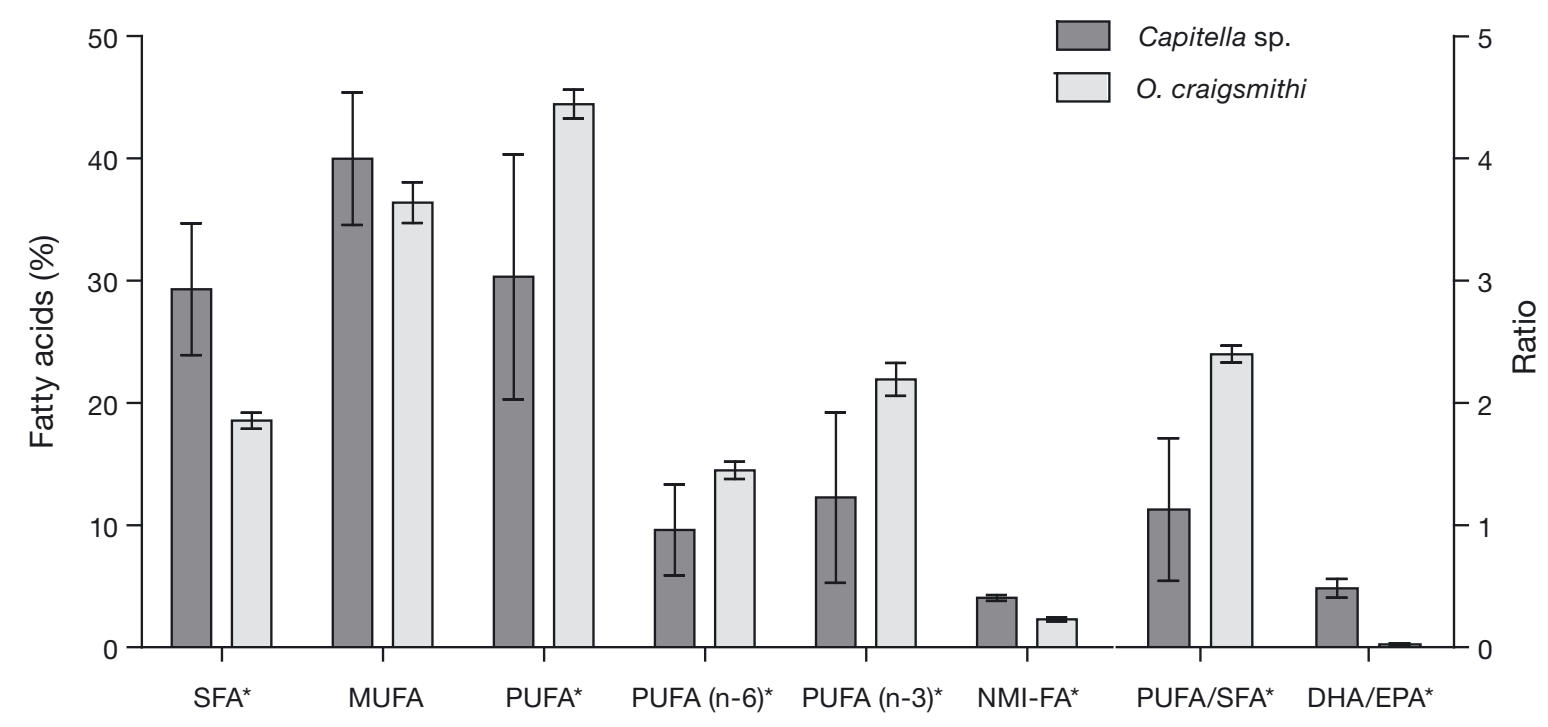

Fig. 3. FA classes (\% of total FAs) and ratios (polyunsaturated [PUFA]:saturated FA [SFA] and docosahexaenoic [DHA]:eicosapentaenoic acid [EPA]) per polychaete species (Capitella sp. and Ophryotrocha craigsmithi). Bars are mean values (n = 12 samples for Capitella sp. and 10 samples for O. craigsmithi); error bars are SD. FA classes or ratios with an asterisk are significantly different between the 2 polychaete species ( $p<0.05)$. All FAs $(>0.1 \%$ of total FAs) were used to calculate the sum of SFAs, monounsaturated FAs (MUFAs), PUFAs, n-6 and n-3 PUFAs or non-methylene interrupted (NMI) FAs 
Table 4. FA composition (\% of total FAs, all defined in Table 3) of the 2 polychaete species (Capitella sp. and Ophryotrocha craigsmithi) fed with the 3 different diets (defined in Table 1). Values are given as means $\pm \mathrm{SD}\left(\mathrm{n}=4\right.$ tanks treatment $^{-1}$, except for $O$. craigsmithi [dried], where $\mathrm{n}=2$ ). Significance as in Table 1. D: diet; S: species

\begin{tabular}{|c|c|c|c|c|c|c|c|c|c|}
\hline & \multicolumn{3}{|c|}{ Capitella sp. } & \multicolumn{3}{|c|}{ O. craigsmithi } & \multicolumn{3}{|c|}{ Significance } \\
\hline & Fresh & Acid & Dried & Fresh & Acid & Dried & $\mathrm{D}$ & $\mathrm{S}$ & $\mathrm{D} \times \mathrm{S}$ \\
\hline SFAs & $30 \pm 3^{b}$ & $23 \pm 1^{\mathrm{c}}$ & $35 \pm 2^{\mathrm{a}}$ & $18 \pm 0.4^{\mathrm{d}}$ & $19 \pm 0.5^{\mathrm{d}}$ & 19 & $* * *$ & $* * *$ & $* * *$ \\
\hline $14: 0$ & $6.6 \pm 0.5^{\mathrm{a}}$ & $4.8 \pm 0.4^{\mathrm{b}}$ & $7.3 \pm 0.8^{\mathrm{a}}$ & $1.2 \pm 0.1^{\mathrm{c}}$ & $1.0 \pm 0.1^{\mathrm{c}}$ & 0.96 & $* * *$ & $* * *$ & $* *$ \\
\hline $16: 0$ & $13 \pm 1^{a, b}$ & $10 \pm 1^{\mathrm{c}}$ & $14 \pm 1^{a}$ & $12.6 \pm 0.4^{\mathrm{b}}$ & $12.9 \pm 0.3^{\mathrm{a}, \mathrm{b}}$ & 12.9 & $* * *$ & $\mathrm{~ns}$ & $* * *$ \\
\hline $18: 0$ & $5.0 \pm 0.6^{b}$ & $4.0 \pm 0.3^{\mathrm{c}}$ & $6.3 \pm 0.3^{\mathrm{a}}$ & $3.2 \pm 0.1^{\mathrm{c}}$ & $3.5 \pm 0.2^{\mathrm{c}}$ & 4.0 & $* * *$ & $* * *$ & $* *$ \\
\hline $20: 0$ & $0.9 \pm 0.1^{\mathrm{b}}$ & $0.7 \pm 0.1^{\mathrm{c}}$ & $1.1 \pm 0.1^{\mathrm{a}}$ & $0.1 \pm 0.01^{\mathrm{d}}$ & $0.1 \pm 0.02^{\mathrm{d}}$ & 0.2 & $* * *$ & $* * *$ & * \\
\hline $22: 0$ & $1.2 \pm 0.6$ & $1.3 \pm 0.2$ & $2.4 \pm 0.5$ & $0.08 \pm 0.03$ & $0.2 \pm 0.1$ & 0.4 & ${ }^{* *}$ & ${ }^{* * *}$ & ns \\
\hline MUFAs & $45 \pm 1^{\mathrm{a}}$ & $33 \pm 1^{c}$ & $42 \pm 2^{\mathrm{a}}$ & $38 \pm 2^{b}$ & $36 \pm 1^{\mathrm{b}, \mathrm{c}}$ & 35 & $* * *$ & $* * *$ & $* * *$ \\
\hline $16: 1(n-7)$ & $3.2 \pm 0.1$ & $2.3 \pm 0.2$ & $2.9 \pm 0.1$ & $4.1 \pm 0.6$ & $4.0 \pm 0.7$ & 4.1 & $*$ & $* * *$ & ns \\
\hline $16: 1(n-9)$ & $0.8 \pm 0.04^{\mathrm{c}}$ & $0.6 \pm 0.04^{\mathrm{c}}$ & $0.7 \pm 0.07^{\mathrm{c}}$ & $3.1 \pm 0.2^{\mathrm{a}}$ & $3.2 \pm 0.1^{\mathrm{a}}$ & 2.8 & ns & $* * *$ & * \\
\hline $18: 1(n-7)$ & $4.2 \pm 0.1^{\mathrm{b}}$ & $3.2 \pm 0.1^{\mathrm{b}}$ & $4.0 \pm 0.2^{\mathrm{b}}$ & $9.7 \pm 0.6^{\mathrm{a}}$ & $9.8 \pm 0.7^{\mathrm{a}}$ & 10.6 & ns & $* * *$ & * \\
\hline $18: 1(n-9)$ & $20 \pm 1^{a}$ & $14 \pm 0.4^{\mathrm{c}}$ & $17 \pm 1^{b}$ & $11 \pm 1^{\mathrm{d}}$ & $9 \pm 1^{d}$ & 8 & $* * *$ & $* * *$ & $* *$ \\
\hline 20:1 (n-7) & $0.9 \pm 0.04^{b}$ & $0.6 \pm 0.02^{\mathrm{c}}$ & $0.8 \pm 0.02^{\mathrm{b}}$ & $0.9 \pm 0.03^{\mathrm{a}, \mathrm{b}}$ & $1.0 \pm 0.08^{\mathrm{a}}$ & 1.3 & $* * *$ & $* * *$ & $* * *$ \\
\hline 20:1 (n-9) & $3.7 \pm 0.2^{\mathrm{a}}$ & $2.6 \pm 0.1^{\mathrm{c}}$ & $3.2 \pm 0.1^{\mathrm{b}}$ & $1.0 \pm 0.2^{\mathrm{d}}$ & $0.6 \pm 0.1^{\mathrm{d}}$ & 0.4 & $* * *$ & $* * *$ & $* * *$ \\
\hline $20: 1(n-11)$ & $4.9 \pm 0.5^{\mathrm{a}}$ & $3.7 \pm 0.1^{\mathrm{b}}$ & $5.4 \pm 0.3^{\mathrm{a}}$ & $4.0 \pm 0.1^{b}$ & $4.1 \pm 0.2^{\mathrm{b}}$ & 4.6 & $* * *$ & $* * *$ & $* * *$ \\
\hline $22: 1(n-9)$ & $0.8 \pm 0.02^{\mathrm{b}}$ & $0.5 \pm 0.04^{\mathrm{c}}$ & $0.8 \pm 0.05^{\mathrm{b}}$ & $1.4 \pm 0.1^{\mathrm{a}}$ & $1.6 \pm 0.2^{\mathrm{a}}$ & 1.8 & ns & $* * *$ & $* * *$ \\
\hline $22: 1(n-11)$ & $2.5 \pm 0.1^{\mathrm{a}}$ & $1.7 \pm 0.1^{\mathrm{c}}$ & $2.2 \pm 0.1^{\mathrm{b}}$ & $0.7 \pm 0.2^{\mathrm{d}}$ & $0.4 \pm 0.04^{\mathrm{e}}$ & 0.3 & $* * *$ & $* * *$ & $* * *$ \\
\hline PUFAs & $25 \pm 2^{\mathrm{b}}$ & $43 \pm 2^{\mathrm{a}}$ & $23 \pm 4^{\mathrm{b}}$ & $44 \pm 2^{\mathrm{a}}$ & $45 \pm 1^{\mathrm{a}}$ & 45 & $* * *$ & $* * *$ & $* * *$ \\
\hline $16: 4(n-1)$ & $3.5 \pm 0.4^{\mathrm{b}, \mathrm{c}}$ & $3.1 \pm 0.1^{\mathrm{c}}$ & $4.3 \pm 0.4^{\mathrm{a}}$ & $3.5 \pm 0.4^{\mathrm{b}, \mathrm{c}}$ & $4.1 \pm 0.3^{\mathrm{a}, \mathrm{b}}$ & 4.2 & $* * *$ & $\mathrm{~ns}$ & * \\
\hline $18: 5(n-1)$ & $0.7 \pm 0.1^{\mathrm{c}}$ & $0.7 \pm 0.01^{\mathrm{c}}$ & $0.8 \pm 0.1^{\mathrm{c}}$ & $1.9 \pm 0.2^{\mathrm{b}}$ & $2.2 \pm 0.2^{\mathrm{a}}$ & 2.5 & $*$ & $* * *$ & * \\
\hline PUFAs (n-6) & $8 \pm 1^{b}$ & $14 \pm 0.4^{\mathrm{a}}$ & $6 \pm 2^{\mathrm{b}}$ & $15 \pm 0.5^{\mathrm{a}}$ & $14 \pm 0.2^{\mathrm{a}}$ & 16 & $* * *$ & $* * *$ & $* * *$ \\
\hline $18: 2(n-6)^{1}$ & $4.6 \pm 0.8^{\mathrm{b}}$ & $7.8 \pm 0.2^{\mathrm{a}}$ & $3.4 \pm 1.0^{\mathrm{b}, \mathrm{c}}$ & $3.2 \pm 0.4^{\mathrm{c}}$ & $2.3 \pm 0.2^{\mathrm{c}}$ & 2.6 & $* * *$ & $* * *$ & $* * *$ \\
\hline $20: 2(n-6)$ & $2.4 \pm 0.2^{\mathrm{b}}$ & $3.8 \pm 0.1^{\mathrm{a}}$ & $2.0 \pm 0.5^{\mathrm{b}, \mathrm{c}}$ & $2.1 \pm 0.4^{b}$ & $1.4 \pm 0.1^{\mathrm{c}}$ & 1.2 & $* * *$ & $* * *$ & $* * *$ \\
\hline $20: 4(n-6)^{2}$ & $0.5 \pm 0.1$ & $1.4 \pm 0.1$ & $0.4 \pm 0.2$ & $7.7 \pm 0.4$ & $8.5 \pm 0.2$ & 10.0 & $* * *$ & $* * *$ & ns \\
\hline PUFAs (n-3) & $8 \pm 1^{\mathrm{b}}$ & $21 \pm 1^{a}$ & $7 \pm 2^{b}$ & $22 \pm 1^{a}$ & $23 \pm 0.3^{\mathrm{a}}$ & 20 & $* * *$ & $* * *$ & $* * *$ \\
\hline $18: 3(n-3)^{3}$ & $1.1 \pm 0.2^{\mathrm{b}}$ & $2.6 \pm 0.2^{\mathrm{a}}$ & $1.0 \pm 0.4^{\mathrm{b}}$ & $1.0 \pm 0.2^{\mathrm{b}}$ & $0.6 \pm 0.1^{b}$ & 0.4 & $* * *$ & $* * *$ & $* * *$ \\
\hline $20: 5(n-3)^{4}$ & $3.1 \pm 0.2^{\mathrm{c}}$ & $9.4 \pm 0.6^{b}$ & $2.9 \pm 1.1^{\mathrm{c}}$ & $18 \pm 2^{a}$ & $20 \pm 0.5^{\mathrm{a}}$ & 18 & $* * *$ & $* * *$ & $* * *$ \\
\hline $21: 5(n-3)$ & $0.5 \pm 0.04^{b}$ & $1.1 \pm 0.1^{\mathrm{a}}$ & $0.5 \pm 0.2^{\mathrm{b}}$ & $0.3 \pm 0.02^{\mathrm{c}}$ & $0.3 \pm 0.02^{\mathrm{c}}$ & 0.3 & $* * *$ & $* * *$ & $* * *$ \\
\hline $22: 5(n-3)$ & $0.6 \pm 0.1^{\mathrm{c}}$ & $1.6 \pm 0.1^{\mathrm{a}}$ & $0.5 \pm 0.2^{\mathrm{c}}$ & $0.9 \pm 0.1^{\mathrm{b}}$ & $0.9 \pm 0.02^{b}$ & 0.7 & $* * *$ & $\mathrm{~ns}$ & $* * *$ \\
\hline $22: 6(n-3)^{5}$ & $1.6 \pm 0.3^{b}$ & $5.1 \pm 0.4^{\mathrm{a}}$ & $1.2 \pm 0.4^{\mathrm{b}, \mathrm{c}}$ & $0.6 \pm 0.1^{\mathrm{c}}$ & $0.5 \pm 0.1^{\mathrm{c}}$ & 0.2 & $* * *$ & $* * *$ & $* * *$ \\
\hline NMI FAs & $4.1 \pm 0.3^{\mathrm{a}, \mathrm{b}}$ & $3.8 \pm 0.1^{\mathrm{b}}$ & $4.2 \pm 0.1^{\mathrm{a}}$ & $2.2 \pm 0.1^{\mathrm{c}}$ & $2.22 \pm 0.02^{\mathrm{c}}$ & 2.6 & $*$ & $* * *$ & $*$ \\
\hline 22:2 NMI & $1.8 \pm 0.2^{\mathrm{a}}$ & $1.6 \pm 0.1^{b}$ & $1.9 \pm 0.1^{\mathrm{a}}$ & $1.0 \pm 0.1^{\mathrm{c}}$ & $1.0 \pm 0.03^{c}$ & 1.2 & $* *$ & $* * *$ & $* *$ \\
\hline PUFA:SFA & $0.8 \pm 0.1^{\mathrm{c}}$ & $1.9 \pm 0.2^{\mathrm{a}}$ & $0.7 \pm 0.2^{\mathrm{c}}$ & $2.4 \pm 0.1^{\mathrm{b}}$ & $2.4 \pm 0.1^{\mathrm{b}}$ & 2.3 & $* * *$ & $* * *$ & $* * *$ \\
\hline DHA:EPA & $0.51 \pm 0.06$ & $0.54 \pm 0.04$ & $0.39 \pm 0.01$ & $0.03 \pm 0.007$ & $0.02 \pm 0.005$ & 0.01 & $* * *$ & $* * *$ & ns \\
\hline
\end{tabular}

PUFA:SFA ratio compared to Capitella sp. fed with the fresh or dried diets (Tukey HSD; $\mathrm{p}<0.001$ ). The lowest docosahexaenoic (DHA):eicosapentaenoic acid (EPA) ratio was observed in O. craigsmithi fed the dried diet (Table 4).

The PCA run on all samples (Fig. 4) separated the polychaete samples from the diet samples. In addition, samples from the 2 polychaete species were also separated from each other (Fig. 4). The first principal component (PC1) explained $81.2 \%$ of the sample distribution and was mainly driven by, in order of relative importance, 22:0, 18:0, 20:5 (n-3), 16:0 and 18:1 (n-7). PC2 explained $15.7 \%$ of the sample distribution and was driven by 20:5 (n-3), 18:1 (n-9), 20:4 (n-6), 14:0, 22:0, 18:0 and 18:1 (n-7). Furthermore, the PCA showed that FA profiles of $O$. craigsmithi were independent of the diets given, which was not the case for Capitella sp. Capitella sp. fed the acid diet differed in FA profile from Capitella sp. fed the fresh or dried diets. For 8 of the 9 FAs mainly driving the differences between the polychaete species in the PCA, a significant species effect was found (Table 4; 2-way ANOVA; $\mathrm{p}<0.05)$; Capitella sp. had a significantly higher content of 14:0, 18:1 (n-9), 18:2 (n-6), 20:2 (n-6) and 22:6 (n-3), while $O$. craigsmithi was richer in 18:1 $(n-7), 20: 4$ (n-6) and 20:5 (n-3). The 2 species did not differ in 16:0 (Table 4; 2-way ANOVA; $\mathrm{p}=0.067$ ). Interestingly, for 7 of the 9 FAs mainly driving the difference between species in the PCA, Capitella sp. fed the acid diet was significantly different from the other treatments (Table 4, Tukey HSD; p < 0.05).

\section{DISCUSSION}

This study shows that, although diets fed to the polychaetes contained relatively low levels of PUFAs (5-9\%), high levels were observed in the poly- 


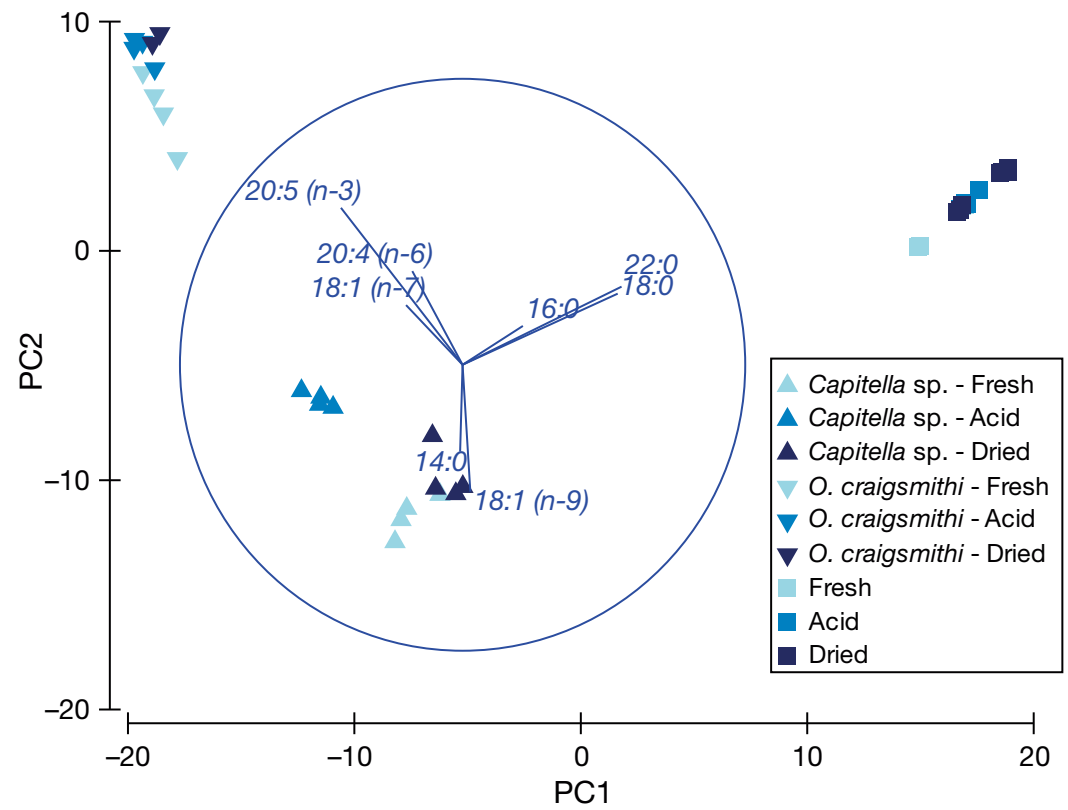

Fig. 4. Principal component analysis (PCA) run with FA profiles of all sample types (see Tables $3 \& 4$ for FA profiles) including the polychaetes (Capitella sp. and Ophryotrocha craigsmithi) and the diets (fresh, acid-preserved and ovendried). PCA was run on untransformed data. Vectors show correlations of $>0.2$

PUFAs are often nutritionally more effective. Atlantic salmon and other marine fish have a restricted activity of $\Delta 5$ and $\Delta 6$ desaturase and elongase and therefore AA, EPA and DHA are required in their diets (Ruyter et al. 2000, Izquierdo 2005, Tocher 2010, 2015). Various alternatives for fish oil have been explored (reviewed by Gatlin et al. 2007). Most alternatives proposed from terrestrial origin do contain ALA and LA, but lack AA, EPA and DHA (Table 5), making them less suitable for diets of marine finfish, except for recent advances in the genetically modified crop Camelina sativa, which now has the potential to include EPA and DHA (Betancor et al. 2017) (Table 5). Alternatives proposed from marine origin, including marine polychaetes, often contain EPA and DHA (Table 5), and are therefore interesting for marine finfish diet formulation.

chaetes (>30\%), including the FAs essential for fish. These results indicate the potential for producing high-quality marine resources using Capitella sp. and Ophryotrocha craigsmithi as extractive species in integrated aquaculture systems. Especially for $O$. craigsmithi, we observed a stable FA profile with high levels of EPA and arachidonic acid (AA). Feeding Capitella sp. with acid-preserved salmon feces enhanced their FA profile in terms of essential FAs. Both species showed highest growth when fed fresh salmon feces. These differences in growth and composition between diets and species have implications for application in coupled and decoupled IMTA systems.

\subsection{Polychaetes as high-quality marine resources?}

O. craigsmithi and Capitella sp. used in the current study were rich in PUFAs ( $>30 \%$ of total FAs) and contained the essential FAs for fish, i.e. $\alpha$-linolenic acid (ALA, 18:3 n-3), linoleic acid (LA, 18:2 n-6), AA (20:4 n-6), EPA (20:5 n-3) and DHA (22:6 n-3), making these polychaetes interesting candidates as alternative ingredients for fish diets. Freshwater fish and salmonids can produce AA, EPA and DHA when the precursors LA and ALA are provided via the diets. For freshwater fish and salmonids, part of their FA requirement can therefore be fulfilled when $\mathrm{C}_{18}$ PUFAs are present in the diet, but the $\mathrm{C}_{20}$ and $\mathrm{C}_{22}$
Although both polychaete species contained the FAs essential for fish, a distinctly different FA signature was observed based on the PCA and statistical comparison between the 2 species. It should be noted that statistical comparisons of 2 species are not always desirable, in particular when studying adaptation (Garland \& Adolph 1994). In the current study, species were statistically compared with the aim of evaluating their potential as ingredients for aquatic diets. $O$. craigsmithi was richer in both n-3 and n-6 PUFAs. In particular, high levels of EPA (19\%) and AA (8.5\%) were observed for O. craigsmithi. Salvo et al. (2015) also reported high levels of EPA and AA in O. cyclops collected underneath aquaculture farms in Newfoundland (Canada), but reported lower values (EPA: $<15 \%$ and AA: $4 \%$ ) than observed in the current study. Similar to Salvo et al. (2015), we also found relatively low levels of DHA $(0.2-0.6 \%)$ for O. craigsmithi, resulting in a low DHA:EPA ratio $(0.02)$. The optimal DHA:EPA ratio reported for several marine finfish (e.g. sea bream, sea bass, halibut and turbot) ranges between 1.3 and 2.08 (Rodriguez et al. 1998, Sargent et al. 1999, Xu et al. 2016), but for Atlantic salmon it has been shown that when diets lack DHA, this can be converted from EPA (Bou et al. 2017). In the current study, Capitella sp. was 6 times richer in DHA compared to O. craigsmithi. The DHA content of Capitella sp. was higher in our study compared to that of Marsh et al. (1990), who reported a DHA content of 


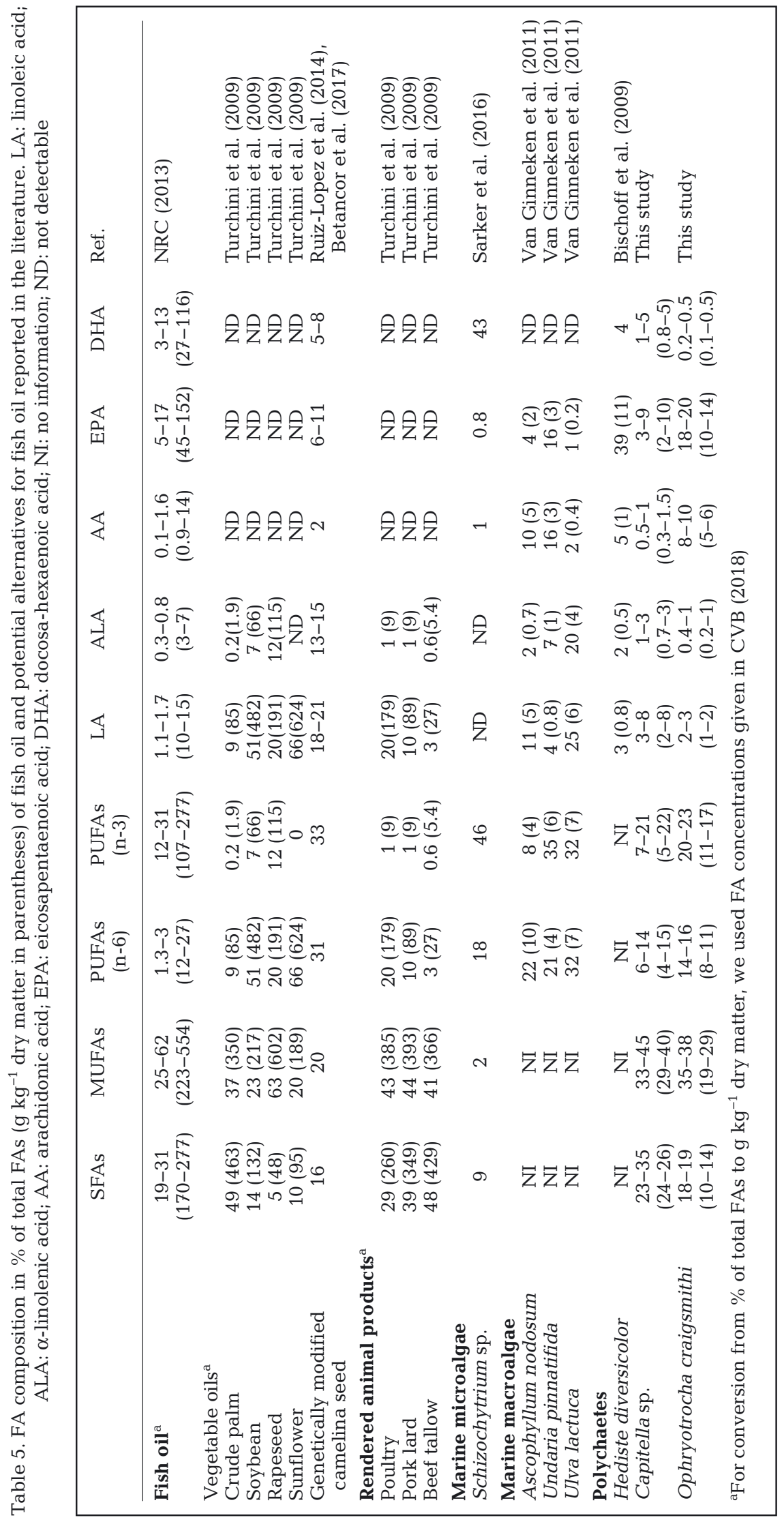

$<1 \%$. Nevertheless, they reported EPA contents of $22 \%$, which is more than 4 times higher than the EPA content of Capitella sp. measured in this study $(5 \%)$. One possible explanation for these differences is that the Capitella sp. used by Marsh et al. (1990) and the Capitella sp. in our study might be different species.

Diets fed to the polychaetes contained low levels $(<1 \%)$ of EPA, DHA and AA, while high levels were observed in the polychaetes themselves. Salvo et al. (2015) also observed high proportions of AA, EPA and 20:2 n-6 in the body of $O$. cyclops, while low levels were found in its food sources. To explain this result, Salvo et al. (2015) proposed 3 hypotheses: (1) even though low levels of certain FAs are present in food sources, accumulation in body tissue may result in increased levels measured in the polychaetes; (2) polychaetes contain enzymes which enable de novo synthesis of particular FAs; and (3) these FAs could have been transferred from bacterial biomass. The diets used in the current study did contain EPA, DHA and AA, albeit at low levels, and therefore all 3 hypotheses suggested by Salvo et al. (2015) could have played a role. Nevertheless, the high levels of AA and EPA in O. craigsmithi compared with Capitella sp. suggests an active enzyme system in $O$. craigsmithi that is able to strongly modify FAs from its diet through elongation and desaturation (Monroig et al. 2013), resulting in an enrichment of the salmon waste by $O$. craigsmithi into essential FAs. De novo synthesis of particular longchain FAs, like EPA, have been demonstrated for some marine polychaetes, including Arenicola marina and Nereis virens (García-Alonso et al. 2008, Olive et al. 2009, Pairohakul 2013). In our study, FA profiles of polychaetes at the start of the experiment were lacking, and it is therefore unknown if the poly- 
chaetes collected underneath salmon farms may already have had enhanced levels of certain FAs, if de novo synthesis did take place and/or if FAs were taken up via bacterial biomass.

FA profiles of $O$. craigsmithi were less influenced by the diets compared to Capitella sp. The multivariate analyses showed that the FA profile of Capitella sp. changed when fed with the acid diet; in particular, the amount of long-chain PUFAs increased. From an aquaculture point of view, feeding Capitella sp. with acidified salmon feces enhanced its FA profile, since a significant increase in ALA, LA, AA, EPA and DHA was observed. The influence of diet on Capitella sp. FA profiles was also shown by Marsh et al. (1990). They reported that FA profiles of Capitella sp. eggs could be distinguished based on the FA profile of diets fed to the individuals producing the eggs. Although in the current study a significantly higher total FA content was observed for the acid diet compared to the fresh and dried diets, the essential FAs were similar to the dried diet and even lower than the fresh diet (in terms of \% of total FAs). Using formic acid to produce fish silage has also been shown to result in a decrease in PUFAs, including DHA, compared to fresh fish (Özyurt et al. 2016). It remains unclear why essential FAs (in terms of \% of total FAs) increased in the Capitella sp. fed with the acid diet. Gene expression of the desaturation and elongation genes may give more insights, but was beyond the scope of this study.

\subsection{Growth performance of polychaetes}

Based on the FA profiles, it can be concluded that both $O$. craigsmithi and Capitella sp. are high-quality marine resources. Besides a suitable FA profile, growth performance on fish waste also determines the potential use of these polychaete species in integrated systems. This study shows that both polychaete species can grow on salmon waste. Other polychaete species studied in integrated aquaculture settings that can grow on fish feces are Nereis virens (halibut feces) (Brown et al. 2011), Hediste diversicolor (eel sludge) (García-Alonso et al. 2008) and Perinereis nuntia vallata (flounder feces) (Honda \& Kikuchi 2002). Growth rates (SGRs) reported in those studies ranged between 0.45 and $2.09 \% \mathrm{~d}^{-1}$, which were lower than the highest SGR of $O$. craigsmithi fed fresh salmon feces in our study $\left(3.6 \% \mathrm{~d}^{-1}\right)$. Given the negative growth rates for $O$. craigsmithi fed the preserved diets, it is questionable if $O$. craigsmithi can be cultivated on salmon feces preserved by drying or by acid- ification. This has implications for the potential use of $O$. craigsmithi in decoupled integrated aquaculture systems, since preservation of fish waste in these systems is recommended. In contrast, Capitella sp. seems to thrive on both preserved and fresh fish waste, as biomass increased in all treatments, although the highest growth rate for this species was also achieved with fresh salmon feces. Successful biomass production of Capitella sp. on fish wastes was also shown in a study by Tsutsumi et al. (2005), where Capitella sp. was cultivated underneath a fish farm in Kuusura Bay, Japan. The highest biomass production was observed in December and January, during which biomass gain was approximately 40-50 g wet weight $\mathrm{m}^{-2} \mathrm{mo}^{-1}$. Converting results of the current study gives a biomass gain of $58 \mathrm{~g}$ wet weight $\mathrm{m}^{-2} \mathrm{mo}^{-1}$ for Capitella sp. fed with the fresh diet, indicating that the results of the current study are comparable to biomass production obtained in the field. Interestingly, in our study, reproduction of Capitella sp. was observed in all treatments. Members of the genus Capitella are opportunistic, and depending on sediment quality they can start reproduction at the age of $4 \mathrm{wk}$, after which they are known for continuous reproduction (Grassle \& Grassle 1976, Levin et al. 1996, Linton \& Taghon 2000). They are described as r-strategists, being able to reproduce fast under unstable conditions (Tsutsumi et al. 2005). In our study, highest reproduction was observed in the acid treatment. The acid diet had the lowest quality in terms of $\mathrm{N}$ and energy, and this contradicts with studies reporting fast reproduction for Capitella sp. in organically enriched sediments (Bridges et al. 1994, Levin et al. 1996, Linton \& Taghon 2000). It remains unclear why we observed the highest reproduction of this species in the acid diet.

We had hypothesized that preserving salmon feces would inactivate microbial activity. Although their exact role is not fully understood, there are indications that microbes play a role in the diets of the 2 polychaete species used in the current study (Findlay \& Tenore 1982, Wiklund et al. 2009a), and this might be an explanation for the lower performance on preserved waste. The difference in performance between $O$. craigsmithi and Capitella sp. may indicate that the role of microbes in the diet of $O$. craigsmithi is more profound. This is supported by Wiklund et al. (2009a) who suggested, based on the P-type jaw structure of $O$. craigsmithi, that microbes, in particular mat-forming large filamentous bacteria, make up an important part of the diet of $O$. craigsmithi. Also, it was shown that underneath fish farms in Canada, part of the diet of $O$. cyclops consists of bacterial mats, but the interaction between polychaete com- 
munities, chemoautotrophic bacteria and organic waste underneath fish farms is not fully understood (Salvo et al. 2015). Furthermore, acidification of waste changed the quality of the diet. Although deterioration can be avoided, acidification is also known to break down proteins in short-chain peptides, and free amino acids (Hardy et al. 1984), which could have disappeared from the preserved waste, decreasing the $\mathrm{N}$ and energy content of the acid diet. The growth of Capitella sp. is related to both organic $\mathrm{N}$ and caloric content of diets (Tenore 1983), which may explain the low growth performance of the polychaetes. On the other hand, the dried diet had an even higher energy content than the fresh salmon feces, which seems to contradict the lower growth performance. However, the hard, condensed structure of this diet may have made it more difficult to consume by the polychaetes (visual observations).

\subsection{Implications for integrated aquaculture}

Results of this study demonstrate that Capitella sp. and $O$. craigsmithi are promising species for converting fish waste into a valuable product with potential for aquatic diets. To assess the full potential of Capitella sp. and O. craigsmithi as extractive species in integrated aquaculture, additional aspects should be considered. The current study focused on FA profiles of the polychaete species, and contributes to the exploration for alternatives for fish oil in aquatic diets. Not only fish oil alternatives, but also fish meal replacers are needed (Tacon \& Metian 2015), and it would be interesting to explore if, based on protein levels and amino acid profiles, Capitella sp. and $O$. craigsmithi cultivated in integrated systems could be regarded as fish meal alternatives. Amino acid profiles of Capitella sp. and O. craigsmithi collected under the fish farms indicated that based on the essential amino acid levels, both polychaete species would fulfil the amino acid requirement reported by the National Research Council (NRC 2013) for Atlantic salmon, tilapia Oreochromis spp. and tiger shrimp Penaeus monodon (Fig. 2). Especially the methionine and lysine content of the polychaete species is of great interest, since these are often the first limiting amino acids reported for plant-based alternatives to replace fish meal in aquatic diets (Van Der Meer \& Verdegem 1996, Furuya et al. 2004). The species-to-species ban of the EU (European Commission 2001) prohibits the re-use of polychaetes cultivated on salmon waste for salmon diets. Nevertheless, based on their amino acid profiles and FA profiles,
Capitella sp. and O. craigsmithi show potential as a high-quality marine resource for other products as well. Next steps in the realization of a polychaetebased aquatic diet should focus on digestibility, attractability and palatability of Capitella sp. and $O$. craigsmithi for fish and shrimp.

Technical issues for integrated cultures should also be considered (Fang et al. 2017). To our knowledge, cultivation and harvesting techniques for marine cultivation of polychaetes have not been developed, although some steps have been taken. Jansen et al. (2018) described a pilot study in which benthic cultivation trays were used to enhance and collect Ophryotrocha spp. underneath salmon farms.

Besides enhancing the productivity of an aquaculture production system, the other major goal of the IMTA approach is to mitigate wastes produced by the fed cultures via extractive species (Chopin 2013, Hughes \& Black 2016). The biomitigation potential of both Capitella sp. and O. craigsmithi should thus be studied to evaluate the overall efficiency and success as extractive species for IMTA systems.

In conclusion, the presence of essential FAs makes both Capitella sp. and O. craigsmithi highly valuable as alternative resources for fish feed formulation. In particular, $O$. craigsmithi is an excellent candidate due to its stable FA profile and high levels of EPA and AA. Feeding Capitella sp. with acid-preserved fish feces enhanced its FA profile. Potential for incorporation in integrated aquaculture systems is not only based on FA content but also the production (growth) potential of polychaetes fed with fish wastes. Fresh feces is the best diet for both species, suggesting that microbes play an important role in the diet of polychaetes. Interestingly, O. craigsmithi showed poor growth performance on preserved fish waste, while Capitella sp. showed some growth, albeit less compared to the fresh diet. Despite the increased FA profiles for Capitella sp. fed on acid diets, growth, and thus production potential, was lower. Overall, $O$. craigsmithi seems suitable for use in integrated open-water systems, where fresh fish feces are continuously supplied to the benthic system, but less for decoupled systems. Capitella sp. could be an interesting species for both open-water and decoupled integrated systems, given that growth was observed on all diets.

Acknowledgements. We thank Lerøy Vest AS and Marine Harvest AS for access to the farms and help with collection of the polychaetes. We thank the technical staff of Austevoll Research Station for experimental set-up and laboratory assistance. We also thank the editor and 3 anonymous 
reviewers for their comments and suggested changes to earlier versions of this paper. This research was supported by Ocean Forest AS (Research and Development license FD0036-1608763/Institute of Marine Research), the Norwegian species initiative and carried out as part of the $\mathrm{PhD}$ study of M.A.J.N. (IPOP project TripleP@Sea KB-24-001-019 at Wageningen University).

\section{LITERATURE CITED}

Bannister RJ, Valdemarsen T, Hansen PK, Holmer M, Ervik A (2014) Changes in benthic sediment conditions under an Atlantic salmon farm at a deep, well-flushed coastal site. Aquacult Environ Interact 5:29-47

Bannister RJ, Johnsen IA, Hansen PK, Kutti T, Asplin L (2016) Near- and far-field dispersal modelling of organic waste from Atlantic salmon aquaculture in fjord systems. ICES J Mar Sci 73:2408-2419

Bergheim A (2012) Recent growth trends and challenges in the Norwegian aquaculture industry. Lat Am J Aquat Res 40:800-807

Beristain BT (2005) Organic matter decomposition in simulated aquaculture ponds. $\mathrm{PhD}$ dissertation, Wageningen University

Betancor MB, Li K, Sprague M, Bardal T and others (2017) An oil containing EPA and DHA from transgenic Camelina sativa to replace marine fish oil in feeds for Atlantic salmon (Salmo salar L.): effects on intestinal transcriptome, histology, tissue fatty acid profiles and plasma biochemistry. PLOS ONE 12:e0175415

Betoret E, Calabuig-Jiménez L, Barrera C, Dalla Rosa M (2016) Sustainable drying technologies for the development of functional foods and preservation of bioactive compounds. In: del Real Olvera J (ed) Sustainable drying technologies. IntechOpen, London, p 37-57

Bischoff AA, Fink P, Waller U (2009) The fatty acid composition of Nereis diversicolor cultured in an integrated recirculated system: possible implications for aquaculture. Aquaculture 296:271-276

Blake JA (2009) Redescription of Capitella capitata (Fabricius) from West Greenland and designation of a neotype (Polychaeta, Capitellidae). Zoosymposia 2:55-80

Bostock J, McAndrew B, Richards R, Jauncey K and others (2010) Aquaculture: global status and trends. Philos Trans R Soc B 365:2897-2912

Bou M, Berge GM, Baeverfjord G, Sigholt T and others (2017) Requirements of n-3 very long-chain PUFA in Atlantic salmon (Salmo salar L): effects of different dietary levels of EPA and DHA on fish performance and tissue composition and integrity. Br J Nutr 117:30-47

Bridges TS, Levin LA, Cabrera D, Plaia G (1994) Effects of sediment amended with sewage, algae, or hydrocarbons on growth and reproduction in two opportunistic polychaetes. J Exp Mar Biol Ecol 177:99-119

Brown N, Eddy S, Plaud S (2011) Utilization of waste from a marine recirculating fish culture system as a feed source for the polychaete worm, Nereis virens. Aquaculture 322-323:177-183

* Buck BH, Troell MF, Krause G, Angel D, Grote B, Chopin T (2018) State of the art and challenges for offshore integrated multi-trophic aquaculture (IMTA). Front Mar Sci 5:165

Budge SM, Iverson SJ, Koopman HN (2006) Studying trophic ecology in marine ecosystems using fatty acids: a primer on analysis and interpretation. Mar Mamm Sci 22:759-801

Chopin T (2013) Aquaculture, integrated multi-trophic (IMTA). In: Christou P, Savin R, Costa-Pierce BA, Misztal I, Whitelaw CBA (eds) Sustainable food production. Springer, New York, NY, p 184-205

Clarke R, Bostock J (2017) Regional review on status and trends in aquaculture development in Europe-2015. FAO, Rome

CVB (2018) CVB veevoedertabel 2018. Federatie Nederlandse Diervoerketen, Lelystad

*Dahlgren TG, Akesson B, Schander C, Halanych KM, Sundberg P (2001) Molecular phylogeny of the model annelid Ophryotrocha. Biol Bull (Woods Hole) 201:193-203

Dahlgren TG, Wiklund H, Kallstrom B, Lundalv T, Smith CR, Glover AG (2006) A shallow-water whale-fall experiment in the north Atlantic. Cah Biol Mar 47:385-389

* Duarte CM, Holmer M, Olsen Y, Soto D and others (2009) Will the oceans help feed humanity? Bioscience 59: 967-976

Eikje EM (2013) Benthic impacts of fish-farm waste on hard bottom habitats, the ecology of opportunistic epifauna polychaetes. MSc thesis, University of Bergen

Espe M, Andersen SM, Holen E, Rønnestad I, Veiseth-Kent E, Zerrahn JE, Aksnes A (2014) Methionine deficiency does not increase polyamine turnover through depletion of hepatic S-adenosylmethionine in juvenile Atlantic salmon. Br J Nutr 112:1274-1285

European Commission (2001) EC Regulation 999/2001 of the European Parliament and of the Council, laying down rules for the prevention, control and eradication of certain transmissible spongiform encephalopathies. EURLex 173:6-13

*Fang J, Zhang J, Xiao T, Huang D, Liu S (2016) Integrated multi-trophic aquaculture (IMTA) in Sanggou Bay, China. Aquacult Environ Interact 8:201-205

Fang J, Jiang Z, Jansen HM, Hu F and others (2017) Applicability of Perinereis aibuhitensis Grube for fish waste removal from fish cages in Sanggou Bay, PR China. J Ocean Univ China 16:294-304

Fauchald K, Jumars PA (1979) The diet of worms: a study of polychaete feeding guilds. Oceanogr Mar Biol Annu Rev 17:193-284

Findlay S, Tenore K (1982) Nitrogen source for a detritivore: detritus substrate versus associated microbes. Science 218:371-373

Froehlich HE, Jacobsen NS, Essington TE, Clavelle T, Halpern BS (2018) Avoiding the ecological limits of forage fish for fed aquaculture. Nat Sustainabil 1:298-303

*Furuya WM, Pezzato LE, Barros MM, Pezzato AC, Furuya VR, Miranda EC (2004) Use of ideal protein concept for precision formulation of amino acid levels in fish-mealfree diets for juvenile Nile tilapia (Oreochromis niloticus L.). Aquacult Res 35:1110-1116

* García-Alonso J, Müller CT, Hardege JD (2008) Influence of food regimes and seasonality on fatty acid composition in the ragworm. Aquat Biol 4:7-13

* Garland T Jr, Adolph SC (1994) Why not to do two-species comparative studies: limitations on inferring adaptation. Physiol Zool 67:797-828

* Gatlin DM III, Barrows FT, Brown P, Dabrowski K and others (2007) Expanding the utilization of sustainable plant products in aquafeeds: a review. Aquacult Res 38:551-579

Goddek S, Espinal CA, Delaide B, Jijakli MH, Schmautz Z, Wuertz S, Keesman KJ (2016) Navigating towards 
decoupled aquaponic systems: a system dynamics design approach. Water 8:303

Grassle J, Grassle JF (1976) Sibling species in the marine pollution indicator Capitella (Polychaeta). Science 192: 567-569

Handå A, Min H, Wang X, Broch OJ, Reitan KI, Reinertsen $\mathrm{H}$, Olsen Y (2012) Incorporation of fish feed and growth of blue mussels (Mytilus edulis) in close proximity to salmon (Salmo salar) aquaculture: implications for integrated multi-trophic aquaculture in Norwegian coastal waters. Aquaculture 356-357:328-341

Hanson RB, Tenore KR (1981) Microbial metabolism and incorporation by the polychaete Capitella capitata of aerobically and anaerobically decomposed detritus. Mar Ecol Prog Ser 6:299-307

Hardy RW, Shearer KD, Spinelli J (1984) The nutritional properties of co-dried fish silage in rainbow trout (Salmo gairdneri) dry diets. Aquaculture 38:35-44

Heip C (1995) Eutrophication and zoobenthos dynamics. Ophelia 41:113-136

Holmer M (2010) Environmental issues of fish farming in offshore waters: perspectives, concerns and research needs. Aquacult Environ Interact 1:57-70

Honda H, Kikuchi K (2002) Nitrogen budget of polychaete Perinereis nuntia vallata fed on the feces of Japanese flounder. Fish Sci 68:1304-1308

*Hughes AD, Black KD (2016) Going beyond the search for solutions: understanding trade-offs in European integrated multi-trophic aquaculture development. Aquacult Environ Interact 8:191-199

Iverson SJ (2009) Tracing aquatic food webs using fatty acids: from qualitative indicators to quantitative determination. In: Kainz M, Brett MT, Arts MT (eds) Lipids in aquatic ecosystems. Springer New York, New York, NY, p 281-307

Izquierdo $M$ (2005) Essential fatty acid requirements in Mediterranean fish species. Cah Options Méditerr 63: 91-102

Jansen HM, Fang, J, Nederlof MAJ, Brennan N, Hansen PK, Samuelsen O, Strand O (2018) Development of benthic IMTA systems by coupling polychaete production to salmon farming: system development, nutrient dynamics and risk of medicine residues. Abstract at the International Conference Aqua 2018, Montpellier, France European Aquaculture Society and World Aquaculture Society

Kinoshita K, Tamaki S, Yoshioka M, Srithonguthai S and others (2008) Bioremediation of organically enriched sediment deposited below fish farms with artificially mass-cultured colonies of a deposit-feeding polychaete Capitella sp. I. Fish Sci 74:77-87

Kirsch PE, Iverson SJ, Bowen WD, Kerr SR, Ackman RG (1998) Dietary effects on the fatty acid signature of whole Atlantic cod (Gadus morhua). Can J Fish Aquat Sci 55: 1378-1386

Klebert P, Volent Z, Rosten T (2018) Measurement and simulation of the three-dimensional flow pattern and particle removal efficiencies in a large floating closed sea cage with multiple inlets and drains. Aquacult Eng 80: $11-21$

Kobayashi M, Msangi S, Batka M, Vannuccini S, Dey MM, Anderson JL (2015) Fish to 2030: the role and opportunity for aquaculture. Aquacult Econ Manag 19:282-300

Kutti T, Hansen PK, Ervik A, Høisæter T, Johannessen P (2007) Effects of organic effluents from a salmon farm on a fjord system. II. Temporal and spatial patterns in in- fauna community composition. Aquaculture 262:355-366

* Lekang OI, Salas-Bringas C, Bostock JC (2016) Challenges and emerging technical solutions in on-growing salmon farming. Aquacult Int 24:757-766

* Levin L, Caswell H, Bridges T, DiBacco C, Cabrera D, Plaia G (1996) Demographic responses of estuarine polychaetes to pollutants: life table response experiments. Ecol Appl 6:1295-1313

* Limin L, Feng X, Jing H (2006) Amino acids composition difference and nutritive evaluation of the muscle of five species of marine fish, Pseudosciaena crocea (large yellow croaker), Lateolabrax japonicus (common sea perch), Pagrosomus major (red seabream), Seriola dumerili (Dumeril's amberjack) and Hapalogenys nitens (black grunt) from Xiamen Bay of China. Aquacult Nutr 12:53-59

*Linton DL, Taghon GL (2000) Feeding, growth, and fecundity of Capitella sp. I in relation to sediment organic concentration. Mar Ecol Prog Ser 205:229-240

Luckstadt C (2008) The use of acidifiers in fish nutrition. Perspect Agric Vet Sci Nutr Nat Resour 3:1-8

*Marsh AG, Gémare A, Tenore KR (1989) Effect of food type and ration on growth of juvenile Capitella sp. I (Annelida: Polychaeta): macro- and micronutrients. Mar Biol 102:519-527

* Marsh AG, Harvey HR, Grémare A, Tenore KR (1990) Dietary effects on oocyte yolk-composition in Capitella sp. I (Annelida: Polychaeta): fatty acids and sterols. Mar Biol 106:369-374

Meier S, Mjøs SA, Joensen H, Grahl-Nielsen O (2006) Validation of a one-step extraction/methylation method for determination of fatty acids and cholesterol in marine tissues. J Chromatogr A 1104:291-298

*Mente E, Coutteau P, Houlihan D, Davidson I, Sorgeloos P (2002) Protein turnover, amino acid profile and amino acid flux in juvenile shrimp Litopenaeus vannamei: effects of dietary protein source. J Exp Biol 205:3107-3122

Mente E, Pierce G, Santos M, Neofitou C (2006) Effect of feed and feeding in the culture of salmonids on the marine aquatic environment: a synthesis for European aquaculture. Aquacult Int 14:499-522

* Miller MR, Nichols PD, Carter CG (2008) n-3 Oil sources for use in aquaculture-alternatives to the unsustainable harvest of wild fish. Nutr Res Rev 21:85-96

* Monroig Ó, Tocher DR, Navarro JC (2013) Biosynthesis of polyunsaturated fatty acids in marine invertebrates: recent advances in molecular mechanisms. Mar Drugs 11:3998-4018

* Murray HM, Gallardi D, Gidge YS, Sheppard GL (2012) Histology and mucous histochemistry of the integument and body wall of a marine polychaete worm, Ophryotrocha n. sp. (Annelida: Dorvilleidae) associated with steelhead trout cage sites on the South coast of Newfoundland. J Mar Biol 2012:202515

Neori A, Chopin T, Troell M, Buschmann AH and others (2004) Integrated aquaculture: rationale, evolution and state of the art emphasizing seaweed biofiltration in modern mariculture. Aquaculture 231:361-391

NRC (National Research Council) (2013) Nutrient requirements of fish and shrimp. The National Academies Press, Washington, DC

O Olive PJW, Duangchinda T, Ashforth E, Craig S, Ward AC, Davies SJ (2009) Net gain of long-chain polyunsaturated fatty acids (PUFA) in a lugworm Arenicola marina bioturbated mesocosm. Mar Ecol Prog Ser 387:223-239

* Ottinger M, Clauss K, Kuenzer C (2016) Aquaculture: rele- 
vance, distribution, impacts and spatial assessments a review. Ocean Coast Manag 119:244-266

Özyurt G, Gökdoğan S, S̨ims̨ek A, Yuvka I, Ergüven M, Kuley Boga E (2016) Fatty acid composition and biogenic amines in acidified and fermented fish silage: a comparison study. Arch Anim Nutr 70:72-86

Pairohakul S (2013) Evidence for polyunsaturated fatty acid biosynthesis in the ragworm (Nereis virens) and the lugworm (Arenicola marina). PhD dissertation, Newcastle University

Rodríguez C, Pérez JA, Badía P, Izquierdo MS, FernándezPalacios H, Hernández AL (1998) The $n$-3 highly unsaturated fatty acids requirements of gilthead seabream (Sparus aurata L.) larvae when using an appropriate DHA/EPA ratio in the diet. Aquaculture 169:9-23

Ruiz-Lopez N, Haslam RP, Napier JA, Sayanova O (2014) Successful high-level accumulation of fish oil omega-3 long-chain polyunsaturated fatty acids in a transgenic oilseed crop. Plant J 77:198-208

Ruyter B, Røsjø C, Einen O, Thomassen M (2000) Essential fatty acids in Atlantic salmon: effects of increasing dietary doses of n-6 and n-3 fatty acids on growth, survival and fatty acid composition of liver, blood and carcass. Aquacult Nutr 6:119-127

Salvo F, Wiklund H, Dufour SC, Hamoutene D, Pohle G, Worsaae K (2014) A new annelid species from whalebones in Greenland and aquaculture sites in Newfoundland: Ophryotrocha cyclops, sp. nov. (Eunicida: Dorvilleidae). Zootaxa 3887:555-568

Salvo F, Dufour SC, Hamoutene D, Parrish CC (2015) Lipid classes and fatty acids in Ophryotrocha cyclops, a dorvilleid from Newfoundland aquaculture sites. PLOS ONE 10:e0136772

Sarà G, Scilipoti D, Milazzo M, Modica A (2006) Use of stable isotopes to investigate dispersal of waste from fish farms as a function of hydrodynamics. Mar Ecol Prog Ser 313:261-270

Sargent J, Bell G, McEvoy L, Tocher D, Estevez A (1999) Recent developments in the essential fatty acid nutrition of fish. Aquaculture 177:191-199

Sarker PK, Kapuscinski AR, Lanois AJ, Livesey ED, Bernhard KP, Coley ML (2016) Towards sustainable aquafeeds: complete substitution of fish oil with marine microalga Schizochytrium sp. improves growth and fatty acid deposition in juvenile Nile tilapia (Oreochromis niloticus). PLOS ONE 11:e0156684

Sissener NH (2018) Are we what we eat? Changes to the feed fatty acid composition of farmed salmon and its effects through the food chain. J Exp Biol 221:jeb161521

Tacon AGJ, Metian M (2015) Feed matters: satisfying the feed demand of aquaculture. Rev Fish Sci Aquacult 23:1-10

Tenore KR (1981) Organic nitrogen and caloric content of detritus: I. Utilization by the deposit-feeding polychaete, Capitella capitata. Estuar Coast Shelf Sci 12:39-47

* Tenore KR (1983) Organic nitrogen and caloric content of detritus III. Effect on growth of a deposit-feeding polychaete, Capitella capitata. Estuar Coast Shelf Sci 17:

Editorial responsibility: Adam Hughes,

Oban, UK
$733-742$

Tocher DR (2010) Fatty acid requirements in ontogeny of marine and freshwater fish. Aquacult Res 41:717-732

* Tocher DR (2015) Omega-3 long-chain polyunsaturated fatty acids and aquaculture in perspective. Aquaculture 449:94-107

* Troell M, Halling C, Neori A, Chopin T, Buschmann A, Kautsky N, Yarish C (2003) Integrated mariculture: asking the right questions. Aquaculture 226:69-90

* Tsutsumi H, Kinoshita K, Srithongouthai S, Sato A and others (2005) Treatment of the organically enriched sediment below the fish farm with the biological activities of artificially mass-cultured colonies of a small deposit feeding polychaete, Capitella sp. I. Benthos Res 60:25-38

Turchini GM, Torstensen BE, Ng WK (2009) Fish oil replacement in finfish nutrition. Rev Aquacult 1:10-57

* Turner JP, Rooker JR (2005) Effect of dietary fatty acids on the body tissues of larval and juvenile cobia and their prey. J Exp Mar Biol Ecol 322:13-27

*Van Der Meer MB, Verdegem MCJ (1996) Comparison of amino acid profiles of feeds and fish as a quick method for selection of feed ingredients: a case study for Colossoma macropomum (Cuvier). Aquacult Res 27:487-495

Van Ginneken VJT, Helsper JPFG, de Visser W, van Keulen H, Brandenburg WA (2011) Polyunsaturated fatty acids in various macroalgal species from north Atlantic and tropical seas. Lipids Health Dis 10:104

* Wang X, Broch O, Forbord S, Handå A and others (2014) Assimilation of inorganic nutrients from salmon (Salmo salar) farming by the macroalgae (Saccharina latissima) in an exposed coastal environment: implications for integrated multi-trophic aquaculture. J Appl Phycol 26: 1869-1878

*Wasta Z, Mjøs SA (2013) A database of chromatographic properties and mass spectra of fatty acid methyl esters from omega-3 products. J Chromatogr A 1299:94-102

Wiklund H, Glover AG, Dahlgren TG (2009a) Three new species of Ophryotrocha (Annelida: Dorvilleidae) from a whale-fall in the North-East Atlantic. Zootaxa 2228: 43-56

Wiklund H, Glover AG, Johannessen PJ, Dahlgren TG (2009b) Cryptic speciation at organic-rich marine habitats: a new bacteriovore annelid from whale-fall and fish farms in the North-East Atlantic. Zool J Linn Soc 155:774-785

Wiklund H, Altamira IV, Glover AG, Smith CR, Baco AR, Dahlgren TG (2012) Systematics and biodiversity of Ophryotrocha (Annelida, Dorvilleidae) with descriptions of six new species from deep-sea whale-fall and woodfall habitats in the north-east Pacific. Syst Biodivers 10: 243-259

* Xu H, Wang J, Mai K, Xu W, Zhang W, Zhang Y, Ai Q (2016) Dietary docosahexaenoic acid to eicosapentaenoic acid (DHA/EPA) ratio influenced growth performance, immune response, stress resistance and tissue fatty acid composition of juvenile Japanese seabass, Lateolabrax japonicus (Cuvier). Aquacult Res 47:741-757

Submitted: October 25, 2018; Accepted: March 25, 2019 Proofs received from author(s): May 16, 2019 